Wayside Shrines: Everyday Religion in Urban India

\title{
Introduction. Wayside Shrines in India: An Everyday Defiant Religiosity
}

Borayin Larios and Raphaël Voix

\section{(2) OpenEdition}

\section{Journals}

\section{Electronic version}

URL: http://journals.openedition.org/samaj/4546

DOI: $10.4000 /$ samaj.4546

ISSN: $1960-6060$

\section{Publisher}

Association pour la recherche sur l'Asie du Sud (ARAS)

\section{Electronic reference}

Borayin Larios and Raphaël Voix, « Introduction. Wayside Shrines in India: An Everyday Defiant Religiosity », South Asia Multidisciplinary Academic Journal [Online], 18| 2018, Online since 20 July 2018, connection on 18 April 2019. URL : http://journals.openedition.org/samaj/4546 ; DOI : 10.4000/ samaj.4546

This text was automatically generated on 18 April 2019

\section{$(1) \Theta \Theta$}

This work is licensed under a Creative Commons Attribution-NonCommercial-NoDerivatives 4.0 International License. 


\section{Introduction. Wayside Shrines in India: An Everyday Defiant Religiosity}

Borayin Larios and Raphaël Voix

Introduction 
1 Although India remains largely rural, approximately a billion people live in cities and megacities throughout its territory. This massive urban concentration is accompanied by a number of social and material rearrangements and innovations that affect the lives of these city dwellers. From the religious perspective, in the last twenty years or so, an increase in modern so-called "mega-temples" has become part of urban religiosity. Examples of this, such

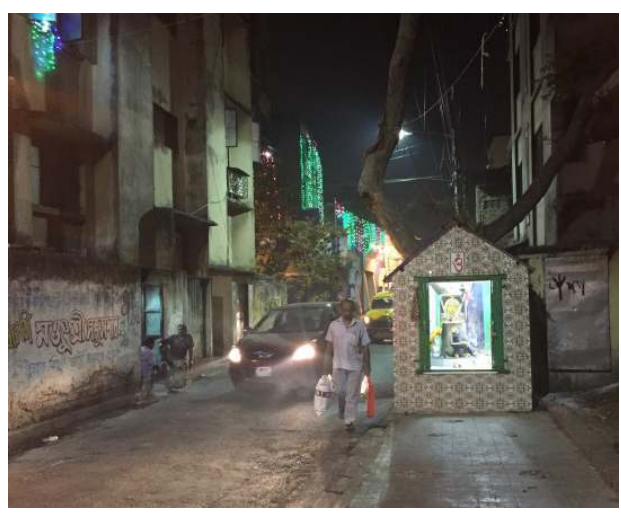
as the Akshardham Temple in New Delhi that simultaneously combines a place of worship, an educational center and an amusement park for its visitors, have attracted the attention of recent scholarship on the creation of a new Hindu public (Singh 2010; Reddy and Zavos 2010; Brosius 2014). Similarly, the religious practices of the urban middle-class, in particular the charismatic movements featuring "mega-gurus" attracting millions of devotees in India and beyond, have likewise drawn recent academic interest (Jacobsen 2014; Nanda 2011; Urban 2003; Warrier 2003).

2 Despite these recent developments in India, Hindu roadside shrines, and similar structures are ubiquitous features of the Indian landscape, particularly in Indian cities. These shrines house divine images favored by their local population. Along with the shrines dedicated to Hindu deities, sanctuaries displaying images or containing remains that commemorate renowned Muslim saints, Mecca or other Islamic pilgrimage centers are also popular, sometimes crossing the boundaries of religious communities. Hindus and Muslims are not the only communities to have popular shrines that are common in the Indian urban landscape; Christian and Buddhist shrines (and to a lesser extent Jain) can also be found mushrooming in the streets of the cities of South Asia, sometimes hosting images from different religious traditions in the same shrine. Shared practices, overlapping images and entangled discourses articulated by a variety of people at these shrines point to the complexity of religious diversity in India.

This issue's hypothesis is that these structures need to be distinguished from institutional "temples/churches/mosques," as well as from "domestic/household" shrines. Although seemingly less spectacular, these heterogeneous shrines play a vital role in contemporary religious life in India. In fact, different systematic surveys of religious structures in Indian cities show that they by far outnumber institutional religious structures. ${ }^{1}$ By bringing together a series of studies undertaken by anthropologists, sociologists and historians, the aim of this issue is to highlight the specificity of these particular places of worship. The volume brings together examples from different regions and cities of India: Goa, Maharashtra, Punjab, Tamil Nadu, Uttar Pradesh and Goa, Amritsar, Chennai, Mumbai, Madurai, Pune and Varanasi. As a heuristic counterpoint we have the example of the Kulung population of a valley with the same name in Nepal. While this issue's intention is to compare shrines of different religions in India, with five articles focused on Hinduism, this tradition remains the principle focus, while the remaining three deal with Christian, Muslim and Tribal shrines.

4 In the first part of this introduction we will briefly review the literature available on shrines in India, showing how it has mainly focused on either large shrines, such as 
institutional places of worship, or the domestic sphere. In the second part, we will specify what we mean by "wayside shrine" and how these structures are distinct from temples/ churches/mosques, on the one hand, and domestic/home shrines, on the other. In the third part, we will look at the specificity of these wayside shrines in relation to the individual, the community and the state.

\section{Brief survey of the literature on Indian shrines}

Research on temple cultures in South Asia and in the Hindu diaspora has a long trajectory. Scholars have studied the phenomenon from different angles of investigation such as the economic, socio-political, ritual, iconographic or the architectural. ${ }^{2}$ For the most part, these studies have addressed single temples or temple compounds/towns structured around a tutelary deity that are large enough to serve as the center of a community, attract patronage from diverse donors, employ priests for their worship, and so on. ${ }^{3}$ In addition there are a number of works centered on pilgrimage practices. ${ }^{4}$ Another area of scholarship on shrines is dedicated to the study of sacred places in the context of non-Brahmanical traditions. Here the focus is often on the tutelary shrines of village gods and (more commonly) goddesses, called grāmadevatās, often believed to be embodiments of basic natural forces and thus representative of an important form of folk religiosity. ${ }^{5}$ Besides the tutelary shrines that protect the village, another important type of structure is the memorial shrine or hero and sati-stones found all over India that commemorate a violent death. ${ }^{6}$ Another relevant area of research is the social and devotional significance of domestic household shrines and the creation of sacred space within the Hindu home both in India and the diaspora. ${ }^{7}$ Finally, an increasing corpus of literature on the production of sacred space in modern South Asian cities is coming out. ${ }^{8}$ Some of this body of work has discussed the recent changes in temple cultures and has, for instance, noted a "construction boom" (Waghorne 2004:4) of temples as part of an emerging urban religiosity.

6 While there is not a single edited publication specifically on the topic of this special issue,

${ }^{9}$ it is nonetheless an emerging field of research with around a dozen isolated studies published so far. ${ }^{10}$ To refer to these shrines, these studies have used different terms: some have referred to their location (street shrines, roadside shrines, roadside temples, pavement shrines) or their size (mini temples, small shrines, miniature shrines). Preston (2002) was one of the first attempts at studying "street-shrines" from a historical perspective. Drawing on material from the early nineteenth century just prior to the British conquest, Preston focuses on the traditional neighborhoods of Pune, revealing that the shrines have a strong place-rootedness and that Sanskritic gods are more likely to be found at the center of the city, while folk and minor deities become part of suburban neighborhoods. Recent urban developments such as the massive expansion of Pune and the repopulation of the city's core after the floods of 1961 remain to be studied. Henn $(2006 ; 2008)$ focuses on Goan urban shrines and concludes that they transform the centuries-old spatio-religious system of Hindus and Catholics to fit the conditions of late modern city life. He attributes the rise in popularity of these shrines to socio-economic change and the increasingly dense and complex flows of motorized traffic. Working in Chennai, Sekine distinguishes "pavement shrines" from "regular" shrines which can be large or small, and which are considerably fewer in number than "pavement shrines." Through his ethnographic example he argues that the "boundary of the dominant 
ideological social space or the boundary between the legal and the illegal in that context maintains a potentiality of producing sacrality" (Sekine 2006:79). In his ethnographic essay on shrines of Chennai, Kalpagam (2006) uses the notion of "multiple modernities" to argue for a framework to better understand the flourishing of contemporary religiosity beyond the spirit of resistance and rather as an expression of working-class religiosity rooted in everyday practices that transcend caste, class, religious and gender boundaries (2006:4599). In turn, Ghassem-Fachandi (2012) describes the emergence of roadside shrines (he calls them "temples") in the city of Ahmedabad as a "mushrooming" phenomenon. He sees these structures as attracting a clientele from a social background that is different from those who patronize regular temples. For him "the success of the structure is predicated on the creative ability to attract the fleeting residents into shortlived economic and spiritual transactions during their daily travel routine to work and back home" (Ghassem-Fachandi 2012:14). He views these "mushroom temples" as sites of "communal identification, conversion, and violent incorporation" (Ghassem-Fachandi 2012:12). Similarly, Shivam's study looks at identity formation in relation to space and argues that "street-side shrines constitute and co-construct an interrelated, open-ended, autonomous space" that is contingent in nature and thus both identity and space "are perennially under construction" (Shivam 2016:61). He argues that street-shrines force us to break away from the classical dichotomies of modernity and religiosity, local and global, and invite us to coin new concepts of sacredness (P. 62). Finally, Lohokare (2016) studies Pune's mitra mandals, which she translates as "associations of male friends" (P. 168) and describes how the inhabitants of these neighborhoods demand a voice in the public life of the city by creatively appropriating the sidewalk and creating a place where religious idiom melds with the social and the civic.

7 Our work draws on these very important contributions, and would like to build on them especially given the enormous variety and scope of religious sensibilities and traditions, regions and material forms wayside shrines can take. In particular, there is a lack of detailed ethnography whose analysis needs to be brought into conversation with larger theoretical interrogations in religious studies and anthropology. By bringing together a series of studies on wayside shrines undertaken by anthropologists, sociologists and historians working in different regions of India, the aim of this SAMAJ-ECSAS special issue is to continue filling this gap.

\section{The notion of "wayside shrines"}

8 In this issue, the authors were free to use the terminology they believed best suited to describe their fieldwork. In fact, many have discussed in detail the taxonomical problem in their contribution. However, we would like to explain the reasons for the choice of the term "wayside shrine" over other possibilities. By using this term we think that, despite its possible pitfalls, ${ }^{11}$ it is still a useful heuristic tool to distinguish different places of worship.

Since its inception in the nineteenth century, the sociology of religion has been confronted with a significant obstacle: the language it uses to speak about religion is embedded in Judeo-Christian religious culture. ${ }^{12}$ The term "shrine" conspicuously used in this volume is one such term. It is derived from the classical Latin scrinium, which meant a container (a chest or a box) for keeping papers and other documents. In its old English form (scrin), it meant a case for relics, and from the fourteenth century onwards it was 
used to designate the tomb of a saint. It then became synonymous with the term "sanctuary" and thus designated a "building set apart for worship." The Oxford dictionary defines the term shrine as "a place regarded as holy because of its associations with a divinity or a sacred person or relic, marked by a building or other construction" (Oxford Dictionary 2017). When the term "shrine" is used to describe elements belonging to other religious contexts, as in our case with South Asia, it can be "problematic" because "its meaning fluctuates" (Schlemmer, this volume). For example, as Henn notes, it can be used both to designate "structures that are distinguished from temples and churches" but also "used to refer to special sites within churches and temples" [Italics ours] (this volume).

10 Nonetheless, this term has the advantage that it is more suitable for denoting structures from different traditions present in South Asia (Hindu, Buddhist, Jain, Sikh, Christian and Muslim) than the synonyms offered by the Oxford Dictionary such as "holy place, temple, church, chapel, tabernacles, altars, sanctuary and sanctum." For instance, calling a dargāh a "Muslim shrine" would probably be acceptable to a majority of Muslims, but calling it a "Muslim chapel" or "Muslim temple" would certainly not be. In addition to being suitable for designating places of worship from different traditions, the term "shrine" has the advantage of enabling the inclusion of structures present within the same tradition but that take on different local names. In Hinduism, but also in Islam, for example, a great variety of terms exist to qualify these sites in different South Asian languages. ${ }^{13}$ Moreover, there seem to be no systematic rules for the terms used since some small shrines can be labeled with the same terms as the larger and more well-established places of worship: it is not easy to find specific emic terms to distinguish a "wayside shrine" from a "temple," or a Muslim roadside shrine from a more institutionalized Sufi tomb ( dargāh)..$^{14}$ Therefore, in this issue, the term "shrine" is used to designate places that can be called by different names at a local level. In other words, it is used as an "etic" neutral signifier that can refer to different "emic" signified..$^{15}$

11 The first occurrence of the expression "wayside shrine" that we were able to find comes from the beginning of the twentieth century. It was used to designate spontaneous "places of offering" on the trail path in Northern California (Goddard 1913). Since then, the expression "wayside shrine" has been used from time to time mostly to designate places of grief or mourning where one would mark the site of a fatality-mainly an accidental death-with particular tributes, such as flowers or photos, and on many occasions a Christian cross. In similar ways-and with little theorization-the term has been used in a variety of regional contexts, for example in Greece where it also refers to mementos celebrating a tragic incident sprouting along public roads, but can in addition be a small prayer edifice where people can enter and pray in their daily life. The expression has also been used recently for the memorials spontaneously built for the victims of terrorist attacks (Monger 1997). Richardson $(1998 ; 2005 ; 2015)$ has also used the expression to designate some places of worship in "Lithuanian folk religion," from "grave markers" to "memorials" of significant events in the life of individuals and communities (2005:250). However, all these different usages of the expression wayside shrine are confined to a specific community and do not offer a clear theoretical framework that might stimulate comparison.

12 It is in the study of shrines in Mauritius by Colwell-Chanthaphonh and de Salle-Essoo's that we find the first elaborate characterization of "wayside shrines." They define "shrine" as "a receptacle, shelter, or building made hallowed by prayer and the 
placement of offerings, which becomes a place of religious veneration and pilgrimage" (Colwell-Chanthaphonh and de Salle-Essoo, 2014:255) and propose three criteria for a shrine to be a "wayside" one: it must be (1) immediately adjacent to, (2) visible from, and (3) publicly accessible to a public roadway. Adjusting this definition to better suit the South Asian context, we propose to demarcate a "wayside shrine" as a site that houses a worshipped object that is immediately adjacent to a public path, visible from it and accessible to any passerby." The emplacement, visibility and accessibility are thus three essential criteria that distinguish wayside shrines from "temple shrines" and "domestic shrines." They have a direct consequence both for the public they affect and for the time that is devoted to the ritual act. For example, people who are in a hurry may find it very convenient to stop at a wayside shrine before an exam, on their way to their workplace, before embarking on a journey or before a medical test. Before entering into greater detail regarding the specificity of these wayside shrines-in the second part of this introduction-we will examine one by one the terms used here and the connotations they evoke.

13 At the core of the "wayside shrine" lies an object-an image, an icon, an idol, a double, a substitute, a container, a manifestation, a seat, etc.-that is being worshiped because it is considered the material incarnation of a specific power, no matter how simple that incarnation may be. However, not all representations of that power can be considered wayside shrines. For example, tiles representing divine figures or saints put on the wall to prevent people from urinating in a particular area would not fall under the category of "wayside shrines." The same tiles, on the other hand, which receive the attention and worship of the devotee can evolve into a shrine. In addition, the object of worship can be an element of nature: for example, in Hindu and Buddhist traditions, trees are frequently the object of ritual practices. Moreover, the objects of worship can also be an aniconic (Figure 1), semi-iconic (Figure 2), or fully iconic (Figure 3). These objects can either be three-dimensional or two-dimensional, such as a photograph, sometimes the original or even a photocopy of an image from a calendar. ${ }^{16}$ Within Hinduism, some of these objects of worship can be self-manifested (Figure 4), while others have been consecrated by a ritual specialist (Figure 5). The object can also be a symbol of a deity (Figure 5), a saint (Figure 6) or a divine transcendent power that evokes said object (relics, amulets, jewelry, mementos, weapons, etc.) (Figure 7). A quick glance at the different divine images enshrined within Hindu wayside shrines shows they are not limited to a specific kind of divinity: it can be a transnational (Figure 8), pan-Indian (Figure 9), or local (Figure 10). ${ }^{17}$ The first criterion for a "wayside shrine" is that the worshipped object must be "immediately adjacent to a public path." The expression "public path" is interesting in that it is sufficiently open to encompass the roads, streets and pavements of South Asian cities, but also public paths within rural areas. While some wayside shrines are located on footpaths and thus encroach on public land (Figure 11)-an important issue to which we will come back later in this introduction-they can also be located on a private wall or private land (Figures 12a, 12b), on a cremation ground (Figure 13), or even in an open air field (Figure 14). While most are inserted within fixed structures, we also find mobile wayside shrines: portable on foot (Figure 15), or affixed to a motorized vehicle (Figures 16a and 16b). Some are ephemeral and/or appear cyclically at the advent of certain festivals (Figure 17), and yet others seem to be built with long-term aspirations in mind (Figure 18). Because of the constraints linked to their location, wayside shrines can encounter significant obstacles to their growth, but they also defy the usual notions of 
positioning and orientation which are so important in temple or mosque shrines. The second criterion for a wayside shrine is visibility. This means that the shrine must be visible from the public path and recognized by the local community as being a place of worship through signs of living practice, for example stones covered with vermilion, flowers, ashes and flags. The third criterion is accessibility: the shrine must be accessible to any passer-by. Contrary to temples, which are gated with a specific entrance that can be guarded and where a passer-by can be refused entrance, wayside shrines remain accessible to anyone. While some can be temporarily enclosed (Figure 18), many are left completely left unguarded and out in the open (Figure 19). Let us note that the shrine's size is not taken into account in the definition of a wayside shrine. First, because size is too subjective a criterion to find a common measure ${ }^{18}$ and second because shrines are dynamic entities: they can grow, extend and sometimes disappear. Wayside shrines vary in size, ranging from extremely tiny free-standing ones, which are not built for people to enter but can serve a small crowd given enough surrounding space (Figure 20), to larger ones, with the 108 feet tall Sankat Mocan Dhām Hanumān Mandir being an extreme example (Figure 21). The vast majority are medium-sized structures where two people can comfortably sit for ritual interactions (Figure 22). Therefore, wayside shrines can be of substantial size, both in architectural details, as well as in the number of people they can attract. While they can start as informal makeshift altars and grow into more institutional shrines, it is our contention that the dynamic of the shrine does not substantially change its raison d'etre, until the moment when it is definitively separated from the rest of the public space and is no longer visible or accessible to anyone.

Thus our preliminary survey from the field, illustrated by the different photographs below, shows that wayside shrines can be found in an almost endless variety of expressions. However, there seem to be many similarities in function between what appears to be a wayside shrine in its simplest expression-a cluster of vermilion-covered stones at the base of a sacred tree-or a shrine that is not built for people to enter that can serve a small crowd according to the surrounding space available, or other shrines which can expand their space by appropriating the surrounding area on special occasions with makeshift structures, such as during annual festivals or even for weekly worship on the traditional day dedicated to the deity.

\section{An everyday defiant religiosity}

16 Authors who have considered the social significance of the quotidian include Michel de Certeau (1984), Fernand Braudel (1982), Michel Foucault (1978), Henri Lefebvre ([1947] 1991) and Mikhail Bakhtin after whom the term "prosaic" was coined (Morse and Emerson 1992) to designate "a way of thinking about human events that focuses on the ordinary, messy, quotidian facts of daily life" (Morson 2013:15). While scholars in the field of religion have emphasized the importance of the mundane and the everyday in its study, few have applied these insights to spatial and material aspects. Orsi, who is one of the exceptions, defines everyday religion in the following way:

not solely or primarily what happens in specially designated and consecrated sacred spaces, under the authority of religious elites, but in streets and alleys, in the souvenir stalls outside shrines, and in bedrooms and kitchens; "everyday religion" does not happen at times determined by sacred calendars or official celestial computations, but by the circumstances and exigencies of people's lives. 
The everyday religious is not performed by rote or in accordance with authority; it

is improvised and situational. (Orsi 2012:150)

Although wayside shrines might appear in many ways as non-threatening to the general public-a reason why perhaps they have been largely ignored by scholarship-these spaces are also an important alternative to more "official" places of worship in the changing social conditions of modern India. McLain (2016) describes commuters who would give darśan daily to a small wayside shrine located near a bus stop without even moving from their bus seat. A woman interviewed explained why she preferred this wayside shrine to a temple shrine:

This street mandir [shrine], it may not look as important as Malaxmi Mandir [one of Mumbai's most famous temples]. But to me it is even more important. It is hard to find time to go to the temple. I work long hours, I have two sons at home and my husband is often out of station for work. Where is the time? I am not so religious that I keep a mandir at home, like my mother did. So, this mandir helps me to make time for God in my life every day. Twice a day I take darshan at this mandir as the bus goes by. Like this, I am able to take darshan and find some peace. (McLain 2016:228)

While, on the one hand, wayside shrines can be considered places of everyday religiosity with seemingly unspectacular consequences, on the other hand they also are certainly "sites of conversion, identity assertion, and injury" (Ghassem-Fachandi 2012:13). During pogroms, Muslim wayside shrines were, on the one hand, the target of violence-they were burned, destroyed or converted into Hindu temples-and on the other, Hindu shrines were used as meeting points from which the attackers proceeded to their targets. Despite what Orsi argues about everyday religion in the quote above, wayside shrines are often subjected to sacred calendars, and while often there is no ritual specialist present at these sites, it is also not uncommon to hire them for special occasions, such as the annual festival of the deity in question or when they are founded, erected and used by political forces, such as the right-wing Vishwa Hindu Parishad (VHP) in Gujarat or the Shiv Sena in Maharashtra.

By using the expression "defiant religiosity" 19 we also highlight what appears to us to be another important characteristic of this kind of space: namely that the practices and discourses that take place at these sites challenge our common conception of "religion" and its usual associations, both in its lay use and in the social sciences (see for example, Asad 1997:115). The concept is challenged because "religion," whether as a stand-alone category or with its signifiers "popular," "folk" or "urban" religion, can no longer imply a coherent system of beliefs and practices that define a particular community. ${ }^{20}$ As Orsi notes: "[p]erhaps it is better to say that everyday religion is the practice of varied strategies of a great refusal" (Orsi 2012:153). As a matter of fact, wayside shrines remain detached from simple dichotomies that often orient scholarship on religion: sacred/ profane, pure/impure, folk/high, authority/agency, etc. They can inhabit them, simultaneously defying the boundaries of clear-cut classifications. The focus on shrines through this lens of the prosaic points beyond the binaries "while at the same time keeping in clear sight the realities of political power, social hierarchies and cultural formations" (Orsi 2012:154). Because of their emplacement in the public space, wayside shrines in many ways defy the individual, the community, and the state. 


\section{Wayside-shrine and the Individual}

18 First, wayside shrines "defy" the passer-by, in the sense that they "confront" him independently of his intention. Contrary to larger or more elaborate temples where the most sacred space (the sanctum sanctorum or garbhagrha, for the Hindus) is accessible only after a selective and voluntary process ${ }^{21}$ that enables the worshipper to enter in a specific attitude or mood, the divine image present in wayside shrines is directly visible to any passer-by, regardless of their socio-economic background and religious affiliation, but also independent of his or her own internal disposition. In the case of Hindu wayside shrines, onlookers can thus suddenly find themselves casually exchanging a glance with the divinity-a practice known as darśana, which is at the core of worship (Eck 1998). This is even so because wayside shrines are so widespread that city residents are likely to regularly and repeatedly encounter divine images as they go about their daily business, and thus, instead of specifically going "for darśan" or approaching the deity in the protected space of the temple that is "giving" darśan, the devotees can simply "take" it. This is an important remark, because as Schlemmer argues wayside shrines are sometimes not "destinations in and of themselves" but rather places one passes by and possibly stops at. The success of wayside shrines is thus dependent "on the creative ability to attract the fleeting residents into short-lived economic and spiritual transactions during their daily travel routine to work and back home" (GhassemFachandi 2012:16).

This direct and individual contact between the wayside shrine and the passerby can thus induce or inspire particular behavior from the latter. As shown in the example of the commuter cited above and in many of the contributions to this special issue, wayside shrines can be sites in which a certain freedom of expression in one's individual worship is possible. Whereas arguably, in Hinduism, individual practices might occur in the everyday private space of the home, in public spaces such as temples, or events such as weddings or other life-cycle rituals, many practices consist in doing exactly what the ritual specialist instructs one to do. For example, one might need to repeat Sanskrit formulas after the priest, or perform ritual gestures as he indicates. In some cases where one's presence is not compulsory or one is not capable of performing the ritual, a specialist can be hired to perform it on one's behalf.

Thus, for many people wayside shrines are places where a certain individual freedom is available. It is also noteworthy that not all shrines have the same amount of ritual activity. Some count one or more professional ritualists working there on a regular basis, while others seem to receive only little formal worship from professional priests or from a particular dedicated caretaker. This freedom associated with the wayside shrines is rooted in the fact that they may often emerge spontaneously or informally in response to individual experiences or visions in which the deity makes itself manifest. This is what Kent explains when she argues that a wayside shrine might very well come into existence because of the interactions of just two beings-the founder and the deity, thus allowing for the display of religiosity of a small group or an individual in the public space. This process is comparable to graffiti or street art, where the individual or collective artistic expression flouts the public space by imprinting potent imagery upon it. Many wayside shrines are in fact born out of the unique vision of an "ordinary" devotee and not a religious authoritative figure, such as an ascetic, priest or saint. Because this is the case, 
wayside shrines are less likely to have an established history linked to them; instead they are either anonymous or related to an individual founder or patron. In fact, according to Kalpagam, one of their particularities is precisely the lack of any "written account of their history." Instead, each one has a unique history that can emerge from "popular histories that need to be pieced together from often contested and oral accounts" (Kalpagam 2006:4596).

\section{Wayside-shrine and the communities}

While the reader has been alerted above to the instrumentalization of shrines for political purposes, and without implying a romanticizing image of wayside shrines as being spaces of resistance, it must be recognized that these places of worship also defy the idea of community in terms of religious exclusivity, class and caste, but also the notions of purity and religious authority.

Wayside shrines defy the monolithic notion of a religious community as an exclusive group, because they offer a space that is more informal and anonymous in nature and that is open to devotees of any caste, class or denomination. Most "established" dargāḥs are also open to devotees from any denomination. The fact that often at these shrines no one will be able to tell or care whether one belongs to a particular religious community or not, and because some of these shrines cater specifically to more than one religious denomination by deploying images and symbols of a number of traditions, these sites engender a religious fluidity that challenges any straightforward religious denomination. Wayside shrines often partially or completely bypass institutionalized religious authority and thus may not be subject to the control of hegemonic groups privileged in official religious institutions. In his contribution to this issue, Henn notes that very often shrines of different religious denominations share the same space, allowing for competing soteriological alternatives and thus communities to coexist. Elison, also in this issue, observes on the basis of shrines in Mumbai that "eclecticism is typical of such displays."

Due to the density and demographic flux where they are often located, these shrines allow a kind of democratization of publics (Henn 2008; Ghassem-Fachandi 2012). Although, wayside shrines are often rightly viewed as an expression of a certain class religiosity, ${ }^{22}$ they are nevertheless able to attract different publics as many of the examples of this volume attest. In many places, central to the annual functions held in wayside shrines is the distribution of the ritually-offered food called bhog, where very different publics meet and exchange: whereas privileged people may go but bring the bhog home to share it, people from underprivileged groups would eat it directly in the street. In her contribution, Østerberg presents the example of a busy shrine that attracts contrasting publics. One of Østerberg's interlocutors at the Hanumān Mandir in Khar Danda considers shrines "like certain spots where the Wi-Fi is good" and thus finds a good connection to her chosen deity. Non-employed women from the lower and middle classes who also visit these shrines, on the other hand, use these sites to fulfill very different needs. For instance, they might visit them to network and chat with neighborhood friends, and/or to find a safe space outside their homes where they can spend "extensive amounts of time in and outside roadside shrines, sometimes up to several hours" (Østerberg, this volume).

If, because of their location, wayside shrines push religion back into the middle of areas of commerce and travel, conversely these places of worship offer venues for mundane 
meetings and exchange. In no way is this combination of ordinary activities with ritual activities unique to wayside shrines; indeed, these take place also in formal temples, especially in the larger temple towns. ${ }^{23}$ However, the general impression is that these institutionalized spaces are much more regulated and based on traditional frames of hereditary trades and economic transactions than at the wayside shrines where there is comparatively much less official control. In his article, Haskett shows that wayside shrines are sometimes places where young and middle-aged men can intoxicate themselves with friends by drinking or smoking marijuana (gañja), a kind of behavior that "would never be possible at the larger, more crowded temples overseen by Brahmins." In some cases wayside shrines are used as spaces in which alcohol, drugs, or other nonBrahmanical substances, are used and offered to the deities. Østerberg notes that the shrines she encountered challenge gendered spaces of normativity by offering alternative spaces to women within urban public space. In this way, visits to wayside shrines can also be a way to escape from the norms and duties of daily life.

While cutting across the usual distinctions between religious affiliation, caste, class or sect, wayside shrines are also places where solidarity emerges and is consolidated. This is the case for the different associations or clubs of friends-usually for males-created around these shrines, like the mitra mandals in Maharastra described by Larios in his contribution or the many shrines that are formed by small-scale collectives. These collectives can be, for instance, a group of rickshaw drivers who decide to set up a shrine to worship the chosen deity collectively before beginning or ending the day, and who specifically ask for the protection over the competition of their autorickshaw fleet and their customers, but also offer thanks for the favors and grace received. Other professionals grouped in small-scale organizations will often create and maintain their own shrines, facilitating not only a sense of community, but also reinforcing their religious identity often beyond sectarian lines. While most of these shrines are built on public space, they can legally belong to a registered trust, or a formal but legally illicit association.

Shrines can also be used as indices of solidarity among certain communities. Some scholars have, for example, remarked on the use of shrines as geographical "markers" or "posts" to mark a certain territory. Mills (2003) for instance observed that for Ladakhis the use of sacred monuments is a way of "nailing down" territory and claiming it as Buddhist (and thus as non-Muslim). Ghassem-Fachandi similarly shows how the erection of shrines in front of Christian NGOs and peace activist organizations is a way of marking a Hindu presence and a provocation and display of power (Ghassem-Fachandi 2012:16). These different solidarities can also participate in larger issues of identity politics resulting in extreme violence as already pointed out above with the cases of the Mumbai Riots of 1992-1993 or the 2002 Gujarat pogroms. As another less violent example, in Goa, there is a nationalist organization called the Gomantak Mandir and Dhaarmik Sanstha Mahasangh (GMDSM), which is currently demanding that the trustees of temples and small shrines in Goa pressure the government to protect their structures. They also call upon the leading devotees (mahājān) to organize themselves and conduct religious classes near/in the temples to instate the "pride for the Hindu Dharma" (Hindu Janajagruti Samiti 2013). During annual festivals, trustees and other leading personalities of different wayside shrines can organize public religious processions where they can assert their local fame while also displaying a Hindu or Muslim identity in what Freitag has called "public arenas" (1989:134). ${ }^{24}$ In certain circumstances wayside shrines can be used as a 
way to resist certain aspects of modern life. Henn notes in this volume that in modern times, one can find various new aspects of social criticism expressed through wayside shrines, serving ecological concerns for instance. Tree shrines, for example, are promoted to prevent the destruction of forests or parks. Wayside shrines can also be a form of resistance that represents common interests, for instance when wayside shrines become a part of protests against the transformation of communal land into private property (see Henn in this volume also).

Yet another way in which wayside shrines mobilize solidarities is through neighborhood associations: "[i]ntensely patriotic, deeply religious, and intent on educational and moral development and community service, these Muslim/Hindu/Dalit collectives fight to better their standing amid intense middle-class accusations of their neighborhoods' decadence and depravity" (Lohokare 2016:167). It is through these shrines and their activities that these collectives refuse to be marginalized. Further, other reasons for erecting and maintaining these shrines might be to create a particular aesthetic and for the very practical reason of keeping a particular space clean. By inviting a deity to inhabit a particular space, even if this space is public, or the deity is traditionally "easy to please" (such as Ganeśa), its presence requires a minimal upkeep and "propitious atmosphere." While subjective categories, cleanliness and pleasant aesthetics (created, for instance, through burning incense, offering oil-lamps, flowers, and other religious consumables) are not only among the common motivations enumerated by patrons and caretakers to erect and keep up shrines, these two aspects also tend to attract larger amounts of devotees than neglected ones.

As the examples in this volume show, it is the micro-politics that determine the spatial growth, expansion, and shift of wayside shrines, which are "more dependent on their immediate surroundings, supportive neighbors or the demographic dominance of a particular community. When the air is filled with communal posturing they inadvertently become, or turn into, community markers" (Ghassem-Fachandi 2012:14).

\section{Illegal wayside shrines and the State of India}

Notwithstanding their long and iconic existence in India, some wayside shrines seem to have become a legal problem in contemporary India. In fact, most of the wayside shrines studied here have emerged by flouting regulations or laws and thus have a peculiar relation to the State.

In Mumbai in 2002, some activists contested the increasing number of what they saw as "illegal religious structures" by filing a Public Interest Litigation. ${ }^{25}$ This specific procedure allows citizens to approach the courts on behalf of the public, whether or not their own rights have been violated. Many authors have noted that because of the judicial activism it enabled, this procedure, since its implementation in India in the 1980s, has deeply affected Indian society, most notably in the domains of poverty, judicial reform and the environment (Sathe 2002; Deva 2010; Bhuwania 2014; Berti and Tarabout 2018). Although these actions are usually filed in the name of the "public," they usually defend a socially embedded vision, and are, in fact, usually controversial among different groups. As argued by Moodie, "PILs have opened up the possibility for the promotion of middleclass interests, as it is particularly men and women of this background who both file and adjudicate PILs" (Moodie, forthcoming). The 2002 Mumbai PILs on "illegal religious structures" are no exception. As pointed out both by Elison and Kent in this issue, the 
people behind these PILs did not represent the various public groups in general, but those of middle-class educated urbanites who defend a vision of a public space that is both "hygienic, orderly and free from religion" (Kent, this volume). In doing this, they were appealing for better control over these structures that were "aggravating the chaotic traffic" (Elison, this volume) in the city and created "unhygienic conditions" (Kent) around those areas. The Bombay High Court pleaded in favor of the PIL by ordering the Municipal Corporation to demolish these structures, which it began to do in 2003 (Janhit Manch v. State of Maharashtra 2002). ${ }^{26}$ Since then, the administration has viewed most of these structures through the lens of their legal status. In the English-language press and in official documents shrines are considered as "illegal religious structures" or "unauthorized religious structures" because many of them encroach on parts of the "public land" (be it a street, park, road, footpath or sidewalk, etc.): either they violate the law as an edifice-i.e. their construction has not been authorized-or because they have not been registered as a social entity (Elison, this volume).

In 2006, based on a news report published by the Times of India mentioning that 1,200 temples and 260 Islamic shrines-including mosques and not just wayside shrines-had encroached upon public space, the High Court of Gujarat issued directions to the various governmental authorities "to take immediate steps for removal of encroachment of religious structures in the public space without any discrimination and submit their reports" ${ }^{27}$. The validity of this High Court order came up for examination before the Supreme Court, which in 2009 gave a judicial blow to "illegal religious structures" when it announced an interim measure according to which:

(i) No unauthorized construction of any religious institution namely, temple, church, mosque or gurudwara, etc. shall be permitted on the public street/public space; (ii) In respect of unauthorized constructions of any religious nature which has taken place in the past, the State Governments would review the same on a case-by-case basis and take appropriate steps. (Union of India v. State of Gujarat \& Ors $2009)^{28}$

It directed all the District Collectors, but also Magistrates and or Deputy Commissioners in charge of the Districts, to ensure that they complied with this order and to submit a report to the Chief Secretaries concerned or the Administrators of the Union Territories who would in turn send a report to the Supreme Court.

The implementation of that interim order led to different State responses. Whereas in West Bengal the State has not yet taken any action to regulate these structures, in other States-like Maharashtra or Tamil Nadu-the administration has inventoried these shrines, and has either regularized, moved or demolished them (or is in the process of doing so). However, this process has faced a great number of difficulties because of the absence of accountability. Many wayside shrines are being located in parts of cities, like slums, that fall outside of municipal jurisdiction and services such as sanitation and policing and where wayside shrines are undocumented. Rather than being understood as illegal, these structures would therefore be better labeled as "extralegal" (Elison 2006:169).

33 Although the court order was legally supreme, in certain cases the local administration itself, for unknown reasons, reluctantly applied it with circumvolution. In Maharashtra, for example, as Larios recalls in this issue, the Bombay High Court had, on several occasions, to "remind the authorities of their duties" (this volume). On October 4, 2010, the State came up with a policy of demolition of illegal religious structures in line with the directions given by the Supreme Court. Surprisingly, on March 14, 2011, the Bombay 
High Court issued a new resolution stating that the implementation of the earlier notification would not be continued and thus stopped the process of demolition of illegal religious structures. However, on May 5, 2011, a new resolution was passed ordering that all illegal religious structures built after September 29, 2009-the Supreme Court order's date-should be demolished. For illegal religious structures constructed before this date, a government resolution distinguished between three types: "(A) those which are required to be regularized; (B) those which cannot be regularized and are required to be demolished; and (C) those which are required to be relocated" ${ }^{29}$. However, until today the government faces great difficulties to apply its own resolution ${ }^{30}$.

The difficulty in demolishing or removing illegal wayside shrines is also compounded by the support these structures have at a local level, both from citizens and politicians. Wayside shrines can be immensely popular: for citizens and neighbors the (il)-legal status of some of these structures has little effect on the way they use them. Working in Chennai, Sekine (2006) notes that ordinary citizens have little regard for the legality of the shrines where they go to worship: for them, the most important criterion is the shrine's "convenience for worship." Therefore, they generally appreciate the appearance of pavement shrines in the vicinity of their houses or offices, be they legal or illegal. In their fully developed stage, some shrines that still illegally occupy a public space can, in fact, "“compete" with "regular/public" (i.e. temple) shrines (Subbiah 2006:84). Moreover, because of their impermanent structures they are places where political connections can be made, notably in cities through the work of the different ward councilors-without whose support some wayside shrines would not exist. In a majority of cases the shrines are under the protection of the police, either freely given or encouraged through bribes. Often police posts rely on the neighborhood networks attached to these shrines, and the more successful the shrines are the more protection they obtain from local political leaders who can mobilize the state apparatus when needed. On the other hand, political parties that back such shrines can count on the mobilization of the devotees attached to these shrines (Ghassem-Fachandi 2012:16). Considering their popularity, it comes as no surprise that when such shrines are removed by the state, in many cases, as in Pune, they are "rebuilt shortly" afterwards (Larios, this volume). As Kent argues in her contribution: "so long as the anthills keep appearing, providing a visible sign of the deity's presence, there will likely be someone to respond to them" (this volume).

With its 2009 ban on illegal religious structures-and although it was applied differently in different regional contexts-the Supreme Court did, in fact, have an effect on the religious life of many people. As Kent argues, nowadays, in this "new legal environment," the waiting period to assess the tolerance of these shrines is met "more swiftly with opposition rather than support, tacit approval, grudging tolerance, or indifference" (Kent, this volume). This power of the Supreme Court to modify the practice of religion is in fact nothing new. Since the time of British rule, in South Asia courts of law have taken on increasing importance in all aspects of human life, from global issues to intimate relationships (Berti and Tarabout 2018). Religious matters are no exception. For example, since the second half of the nineteenth century, courts of law have come to adjudicate conflicts concerning endowments and various temple issues. Since Independence in India the courts-and most notably the Supreme Court-have acquired an even more crucial role in the shaping of religion. ${ }^{31}$ The examples included in this volume also show how, through their actions, courts in India shape the place religion occupies in public space. By doing so, they participate in the secularization process by downplaying the public 
expression of religious fervor, although not without contestation from the different parties involved.

\section{Conclusion}

As the papers in this special issue demonstrate wayside shrines have the potential to disrupt and challenge the assumptions and practices at stake in more institutionalized and male-controlled religious sites. They give voice and agency to actors in unique ways and sustain a mode of religiosity that fits well into Orsi's concept of "everyday religion" (Orsi, 2012). By providing a seemingly less hierarchical environment where the asymmetrical relations of caste and gender link together differently, they can, for example, be safe havens for women to navigate the urban public space, or can offer a convenient way to connect with a higher power in the everyday life of the urban subject. While waysides' emplacement is crucial and the allegiances of their visitors are primarily local, these shrines are neither isolated nor exclusively concerned with local issues. The evidence presented in this volume shows that, in fact, wayside shrines are, not only fully engaged with the modern world at large, they are also idioms of popular culture that can generate new forms of religious practice, such as the drive-through darśan (Larios in this volume).

While wayside shrines contribute to the construction of a sense of belonging to specific localities where diverse religious communities can connect and participate in a shared sense of identity, they are also sites that can, on the contrary, become provocative markers of religious intolerance and violence. Thus they can appear as defiant sites at three different scales: at the level of the individual, of the community, and of the state. While this defiance is not always intentional, its power as a disruptive force can be attested at all three levels: in the way a wayside shrine alters a pedestrian's behavior on the sidewalk, or as it offers a safe space for a collective of marginalized individuals to express their devotion in unorthodox ways, or when shrines become a way to illegally encroach upon the public space.

By focusing on a vital strand of everyday religiosity wayside shrines force us to focus on a bottom-up perspective and invites us to closely consider the practices of "lived religion." We see this rich collection of articles as the continuation of a fruitful conversation and we hope that it will inspire further scholarship around these kinds of religious sites in South Asia and beyond.

\section{Figures}


Figure 1

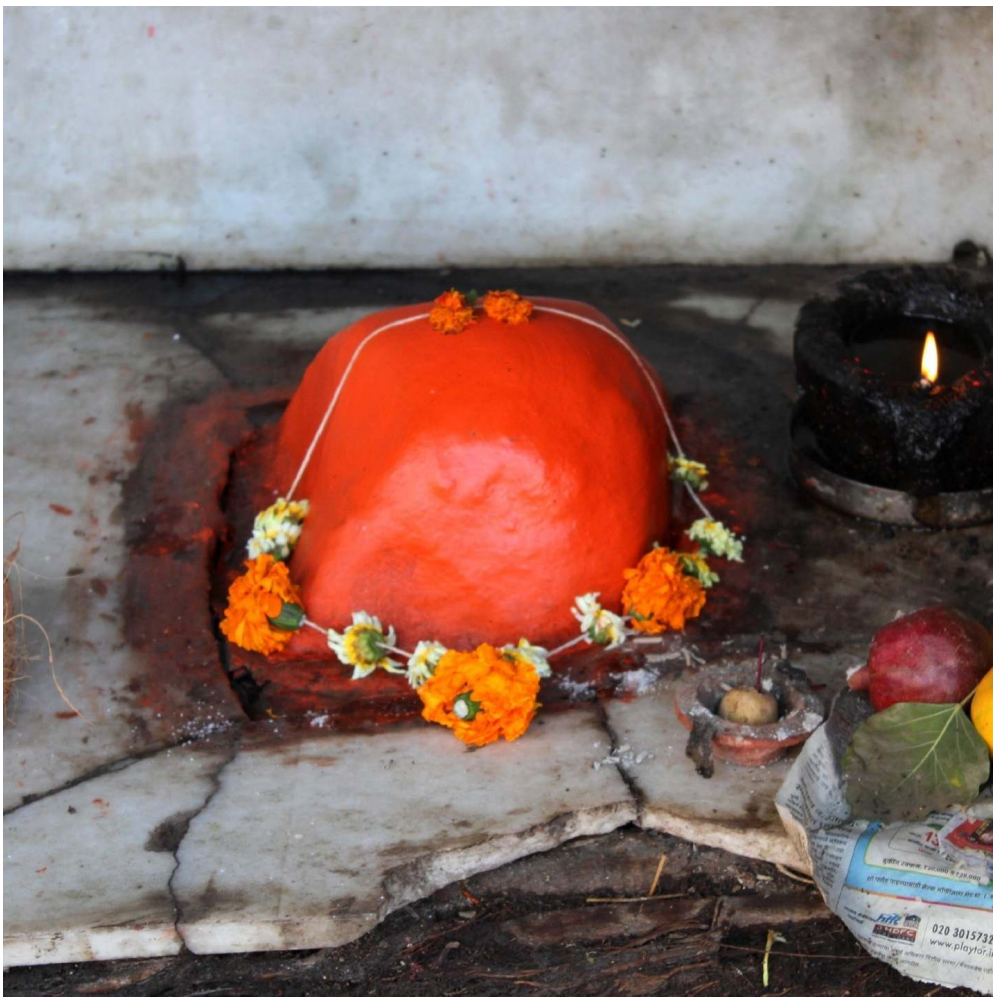

Niche on a wall with an aniconic deity (Mhasoba or Śiva) Shukrawar Peth, Pune, Maharashtra. Photo credits: Borayin Larios. 
Figure 2

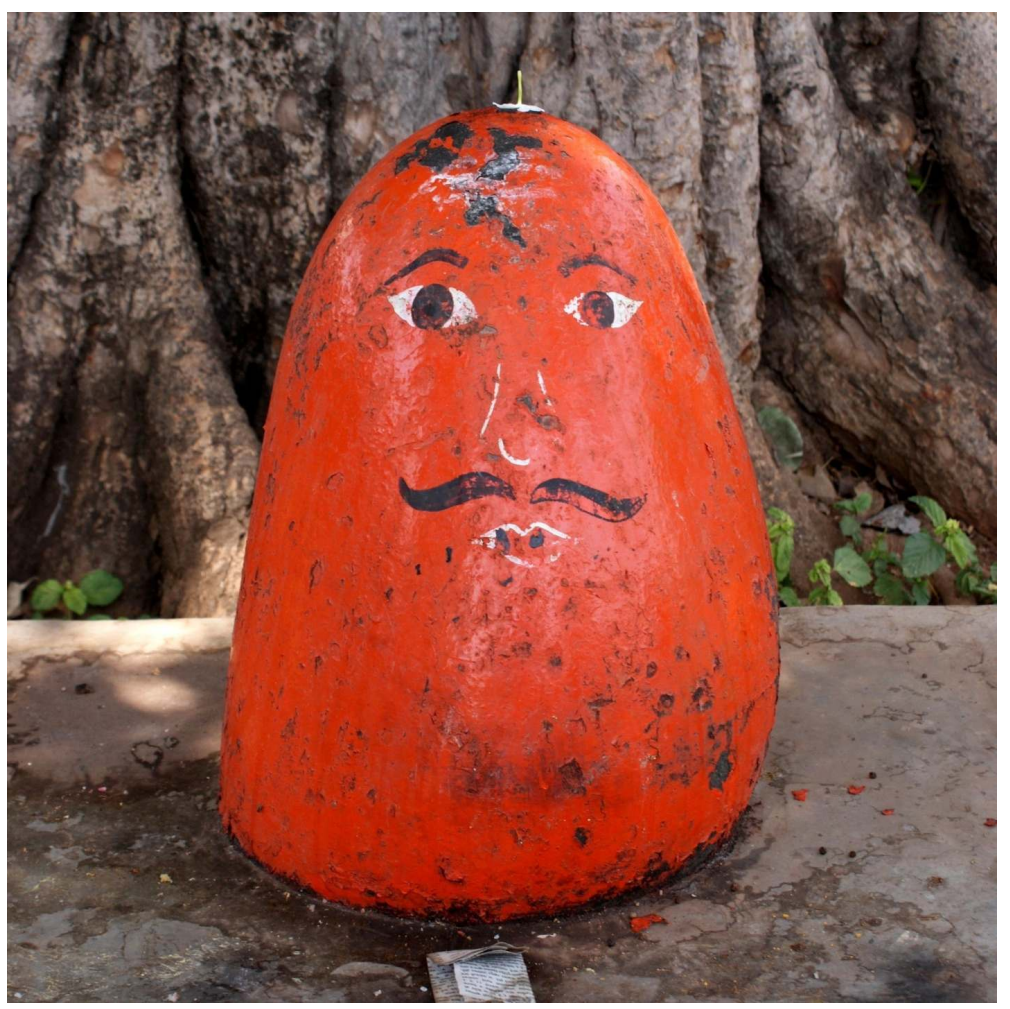

Śivalinga with semi-iconic traces depicting an anthropomorphic face. In Kolhapur, Maharashtra. Photo credits: Borayin Larios 
Figure 3

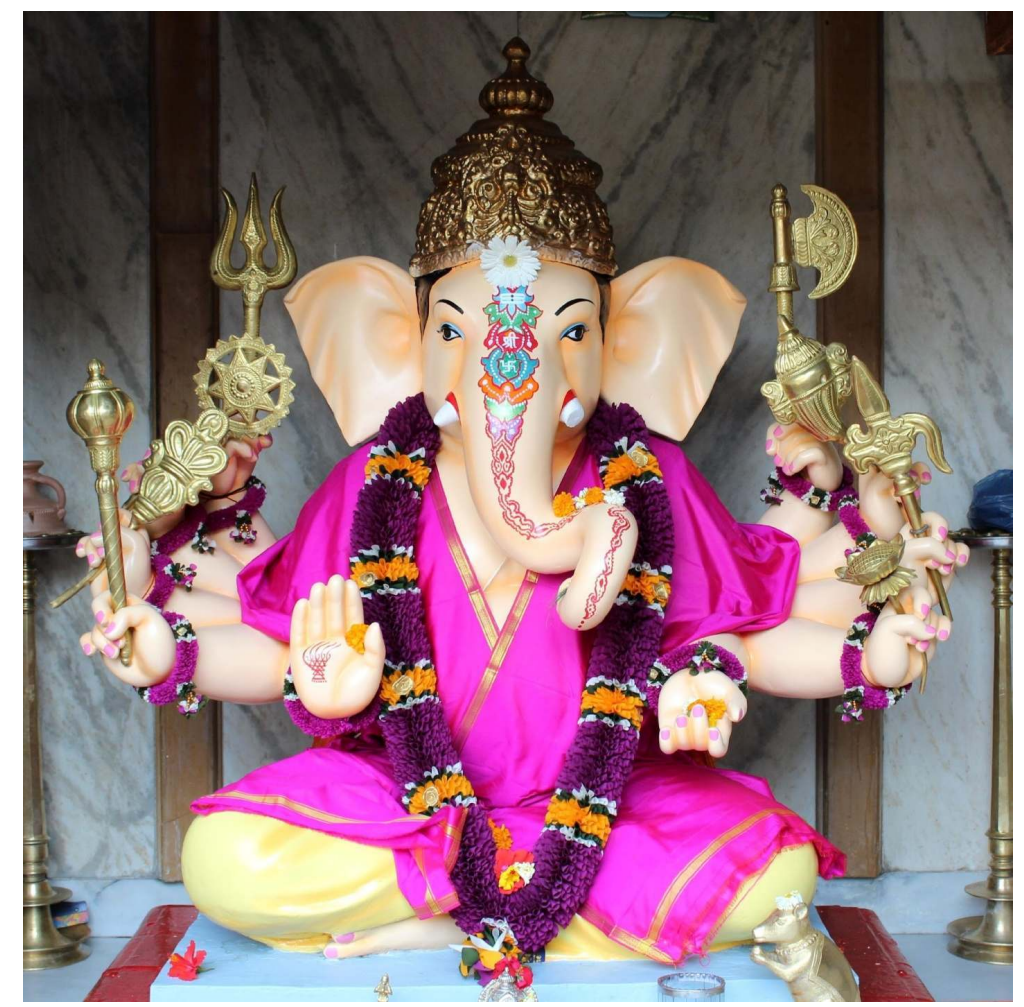

Fully iconic image of Daśabhuja Gaṇpatī in Budhwar Peth/Shukrawar Peth, Pune, Maharashtra. Photo credits: Borayin Larios.

\section{Figure 4}

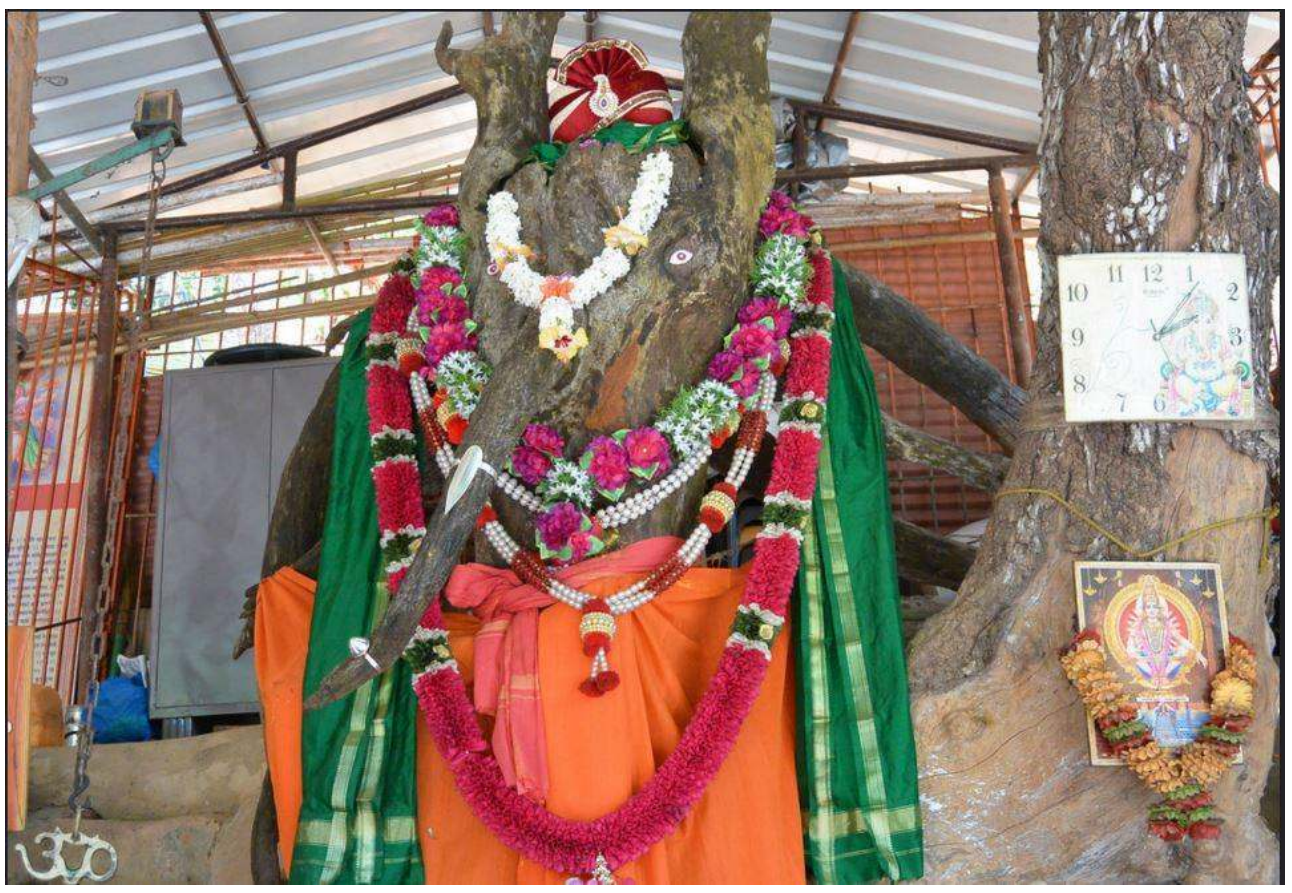

Wayside temple with the form of Ganeśa emerging naturally out of a tree on the NH 66, Barcem, Goa. Photo credits: Borayin Larios. 
Figure 5

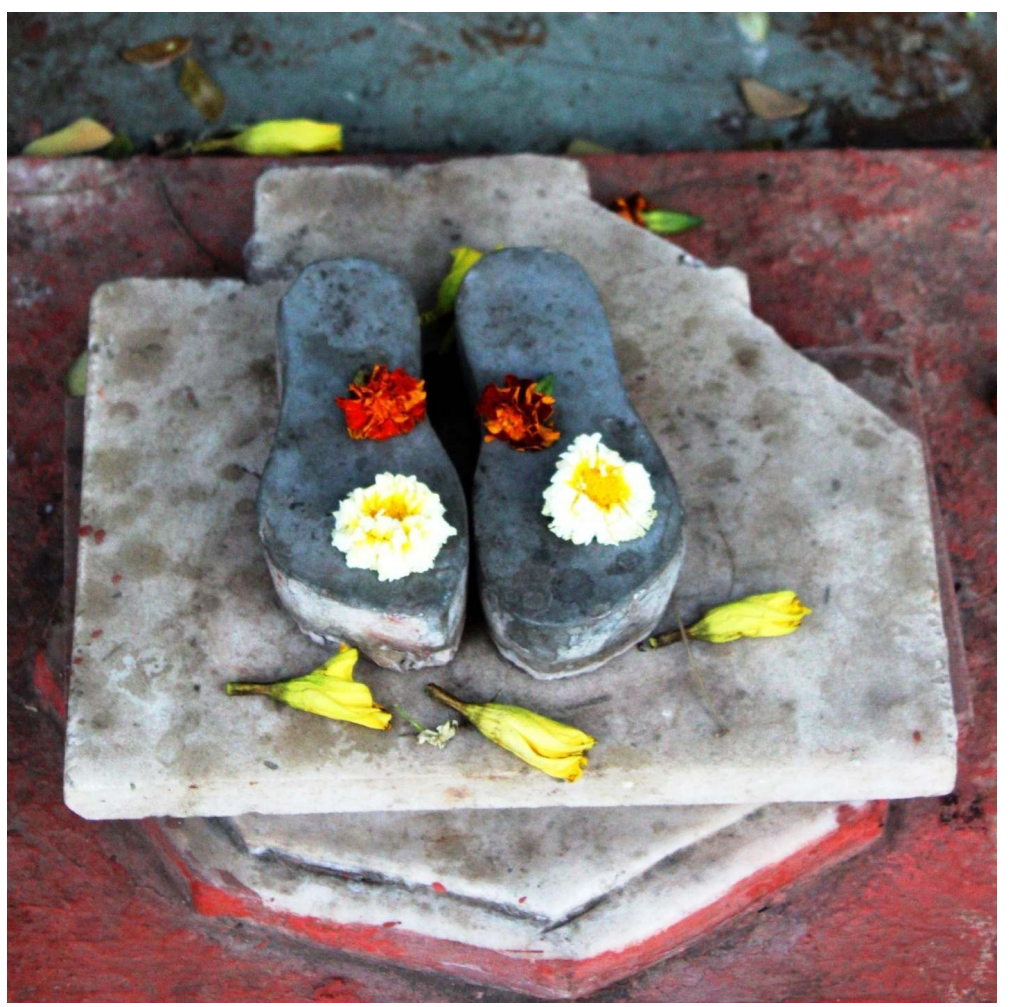

Dattātreya's footwear under a tree represented in stone. Kamala Nehru park, Pune, Maharashtra. Photo credits: Borayin Larios. 


\section{Figure 6}

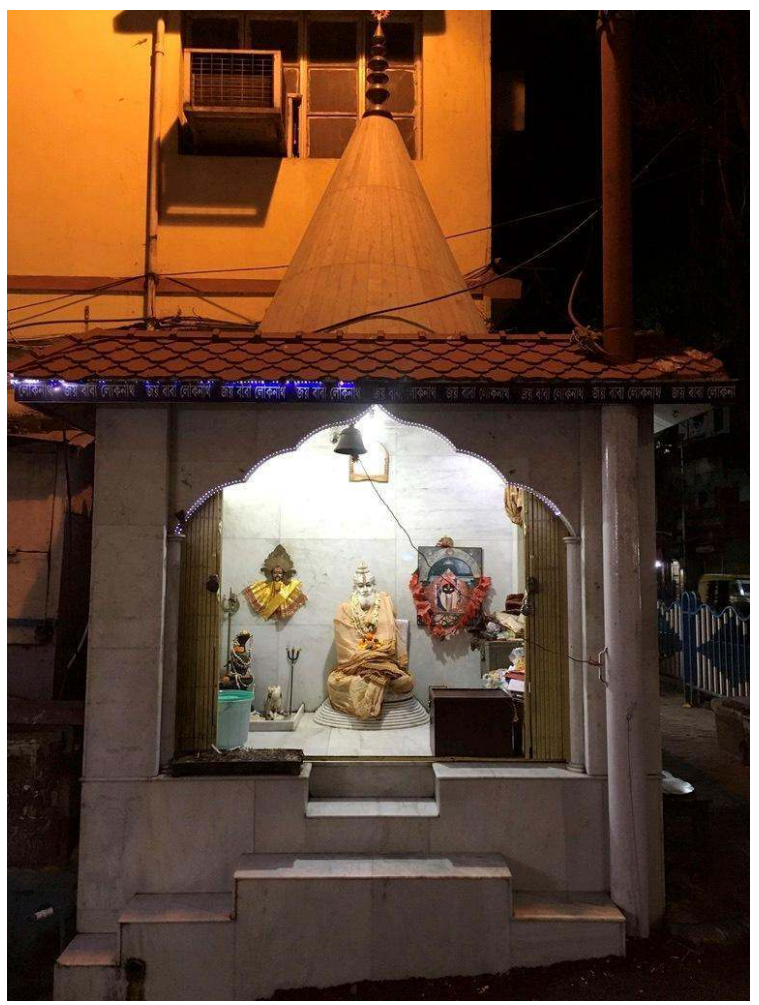

Wayside shrine dedicated to the Bengali saint Lokenāth Brahmacārī, Tollygunge, Kolkata. Photo credits: Raphaël Voix. 
Figure 7

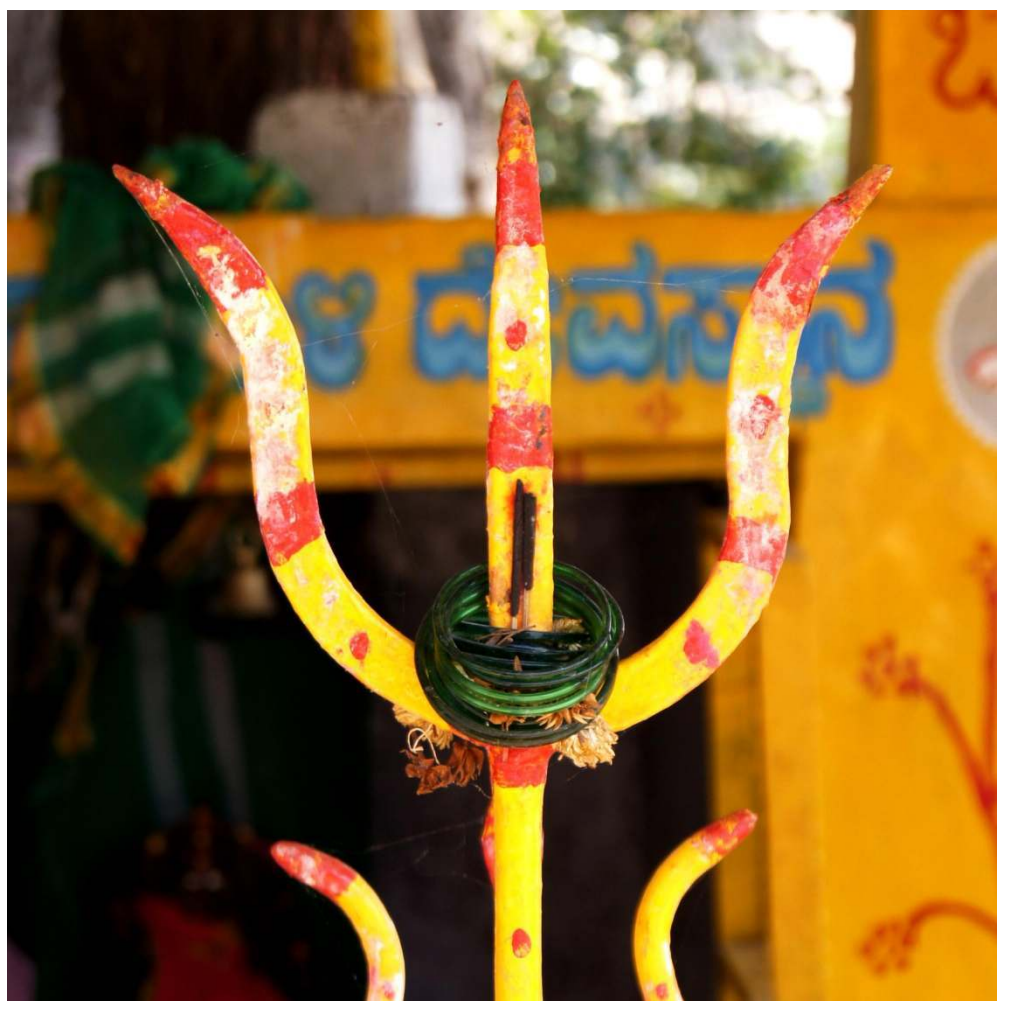

Trident and glass-bangles of the Goddess Durgā. Hampi, Karnataka. Photo credits: Borayin Larios. 
Figure 8

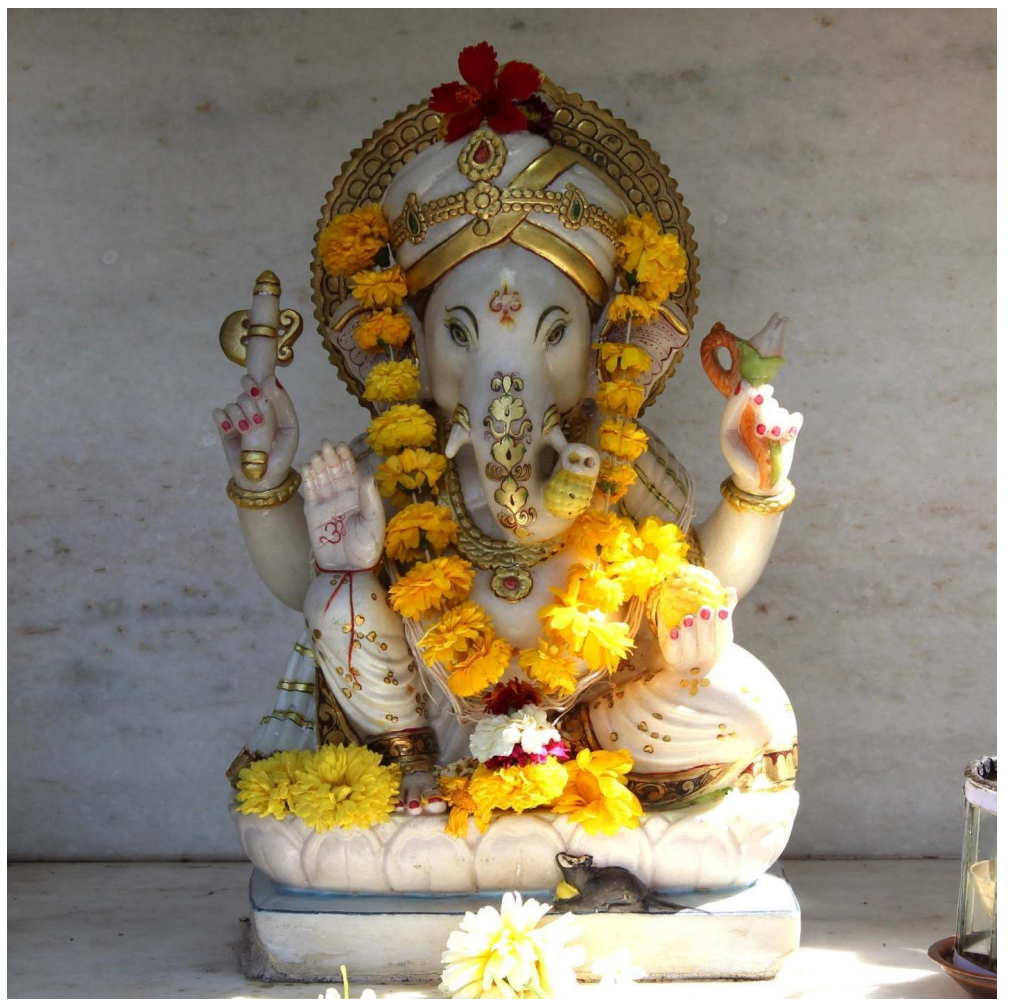

The popular god Ganeśa with a turban. Aundh, Pune, Maharashtra. Photo credits: Borayin Larios. 


\section{Figure 9}

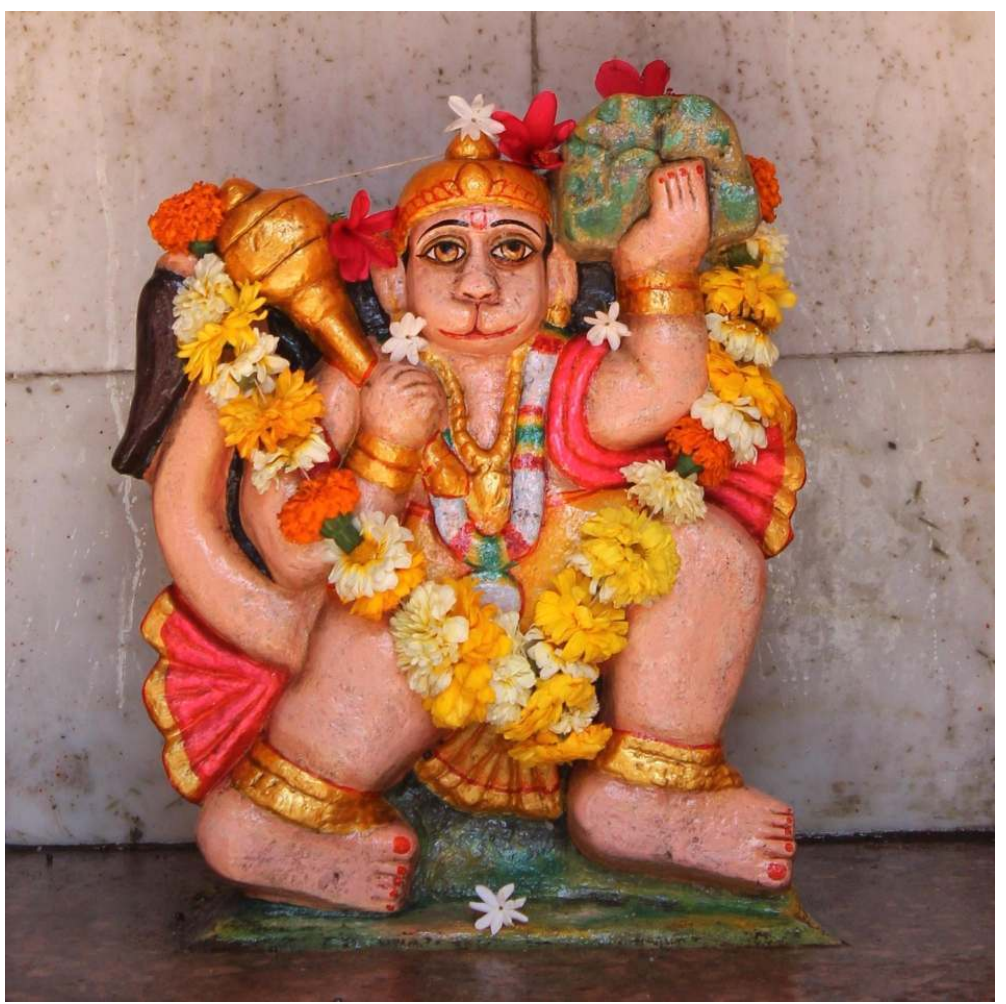

Hanumān carring the Sanjīvanī mountain. Budhwar Peth, Pune, Maharashtra. Photo credits: Borayin Larios. 
Figure 10

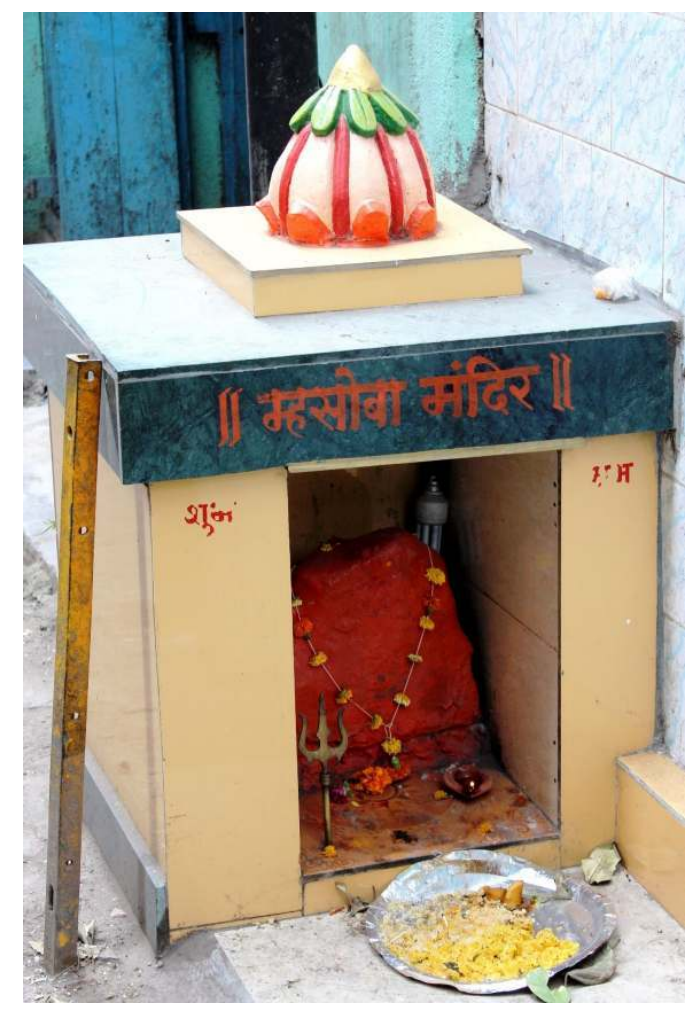

A tiny temple dedicated to the pastoral deity Mhasobā from Maharashtra. Budhwar Peth, Pune, Maharashtra.

Photo credits: Borayin Larios.

\section{Figure 11}

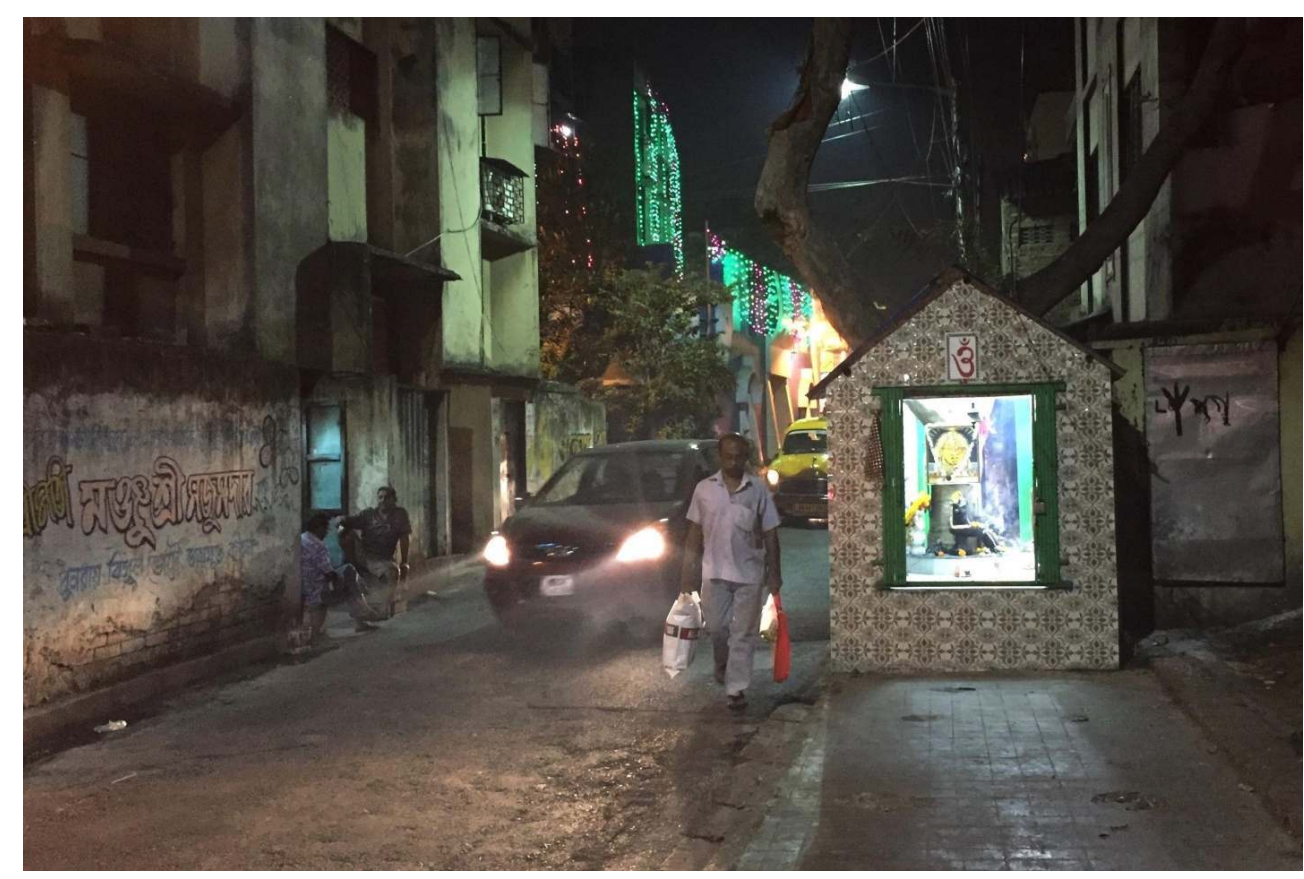

A man walking on the street because a wayside-shrine has been erected on the footpath blocking his way, Kolkata.

Photo credits: Raphaël Voix. 
Figure 12a

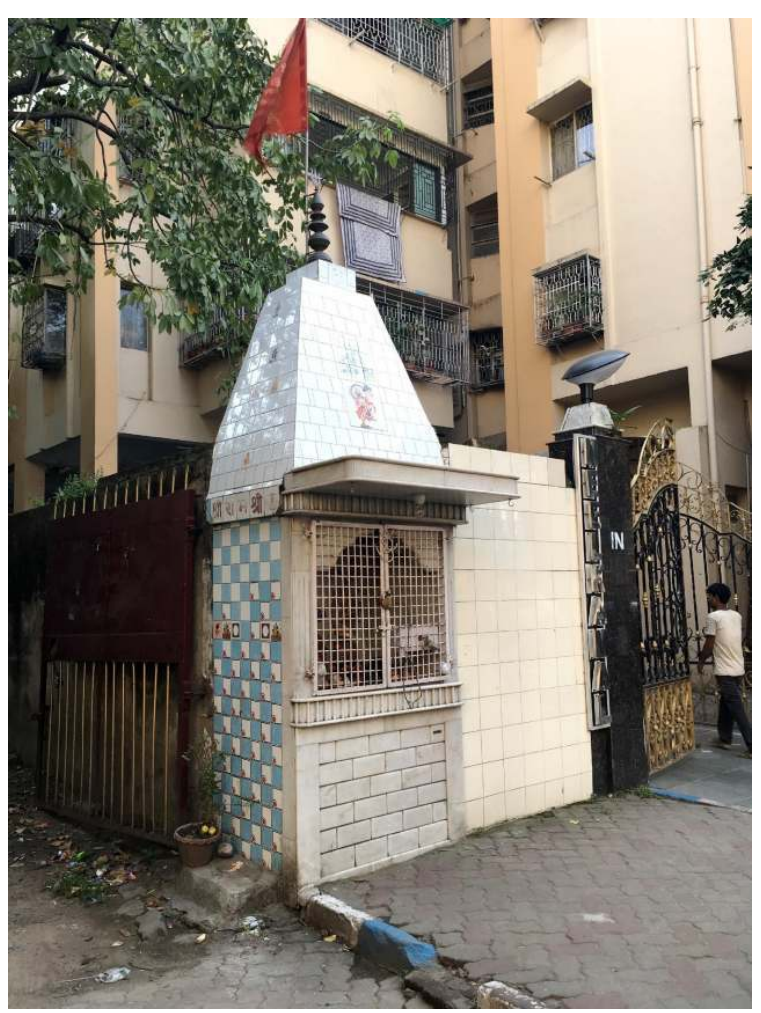

Wayside shrine located at the entrance of a building on a private wall, Kolkata. Photo credits: Raphaël Voix. 
Figure 12b

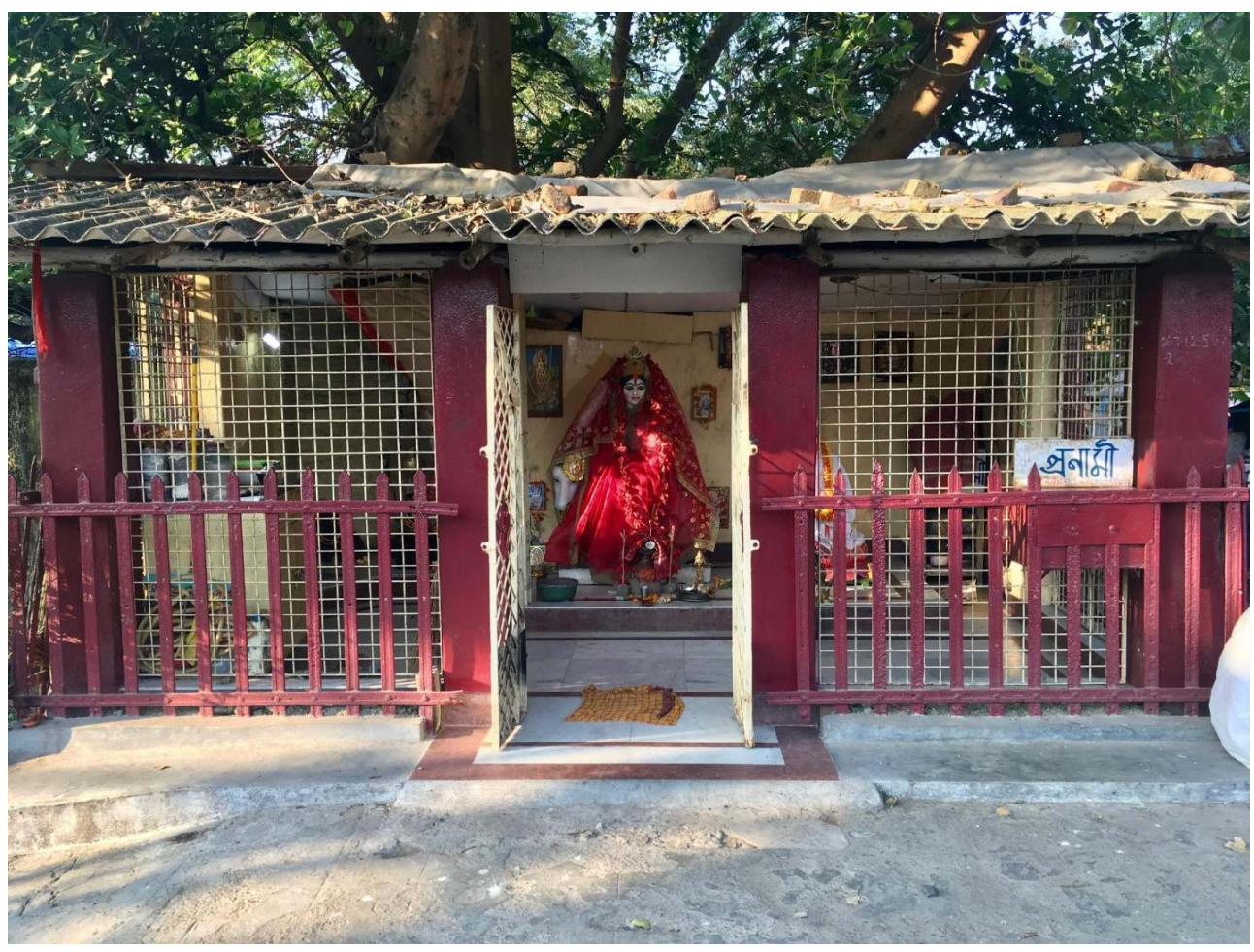

Wayside shrine located on private property right next to the footpath and meant to be accessible to any passerby.

Photo credits: Raphaël Voix.

Figure 13

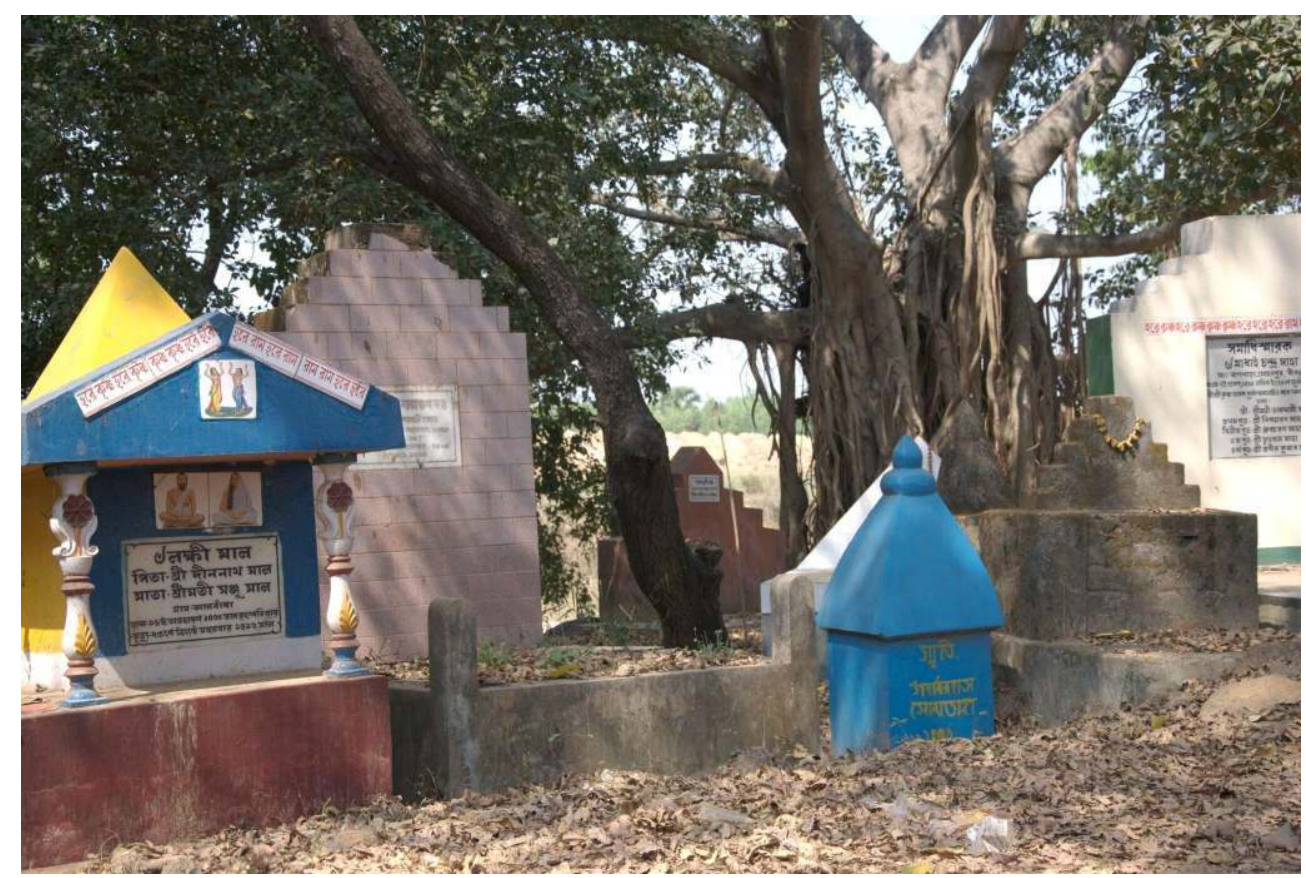

Wayside shrine located on a cremation ground, West Bengal.

Photo credits: Raphaël Voix. 
Figure 14

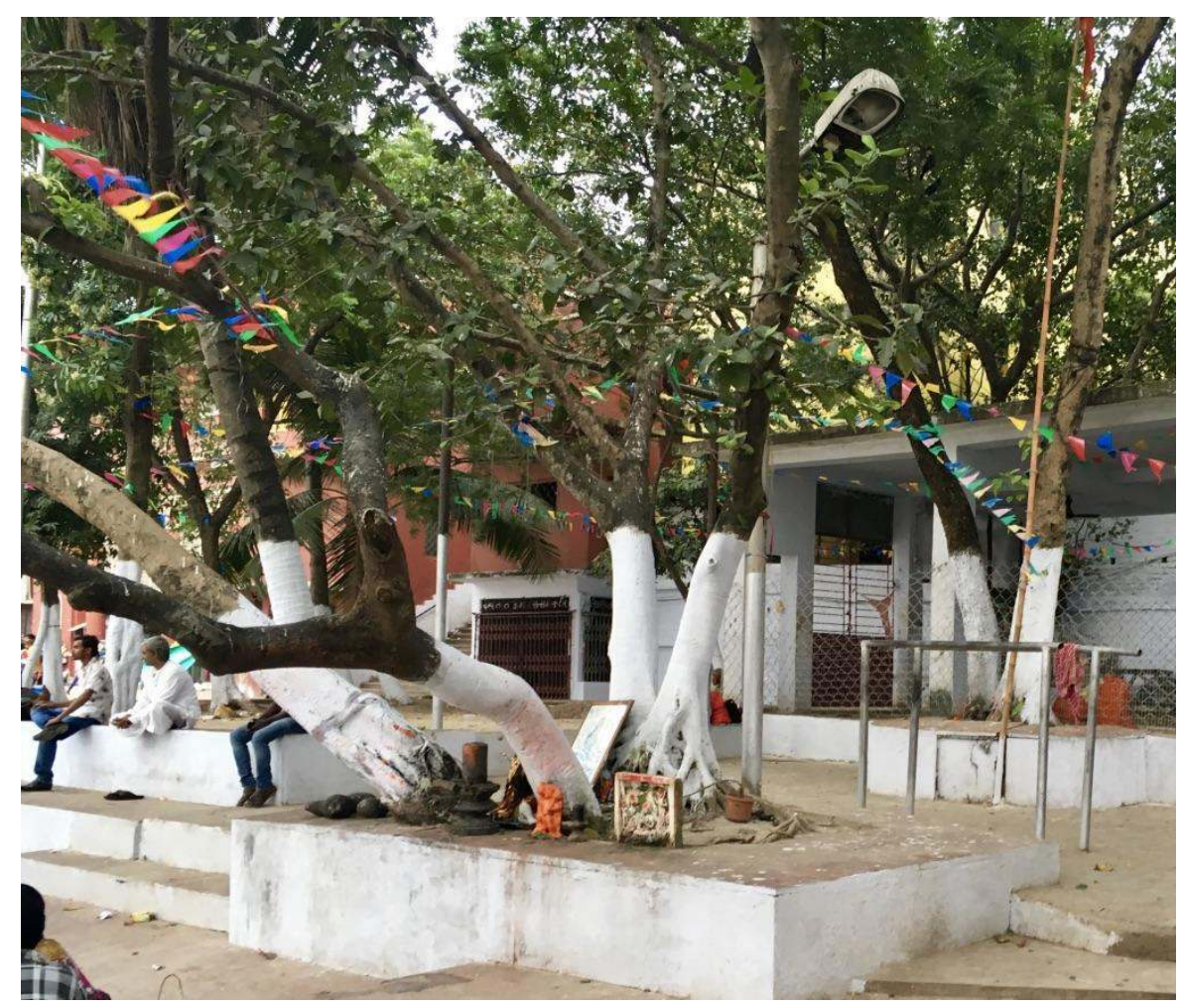

Open-air wayside shrine located on a bathing ghat, Kolkata.

Photo credits: Raphaël Voix. 
Figure 15

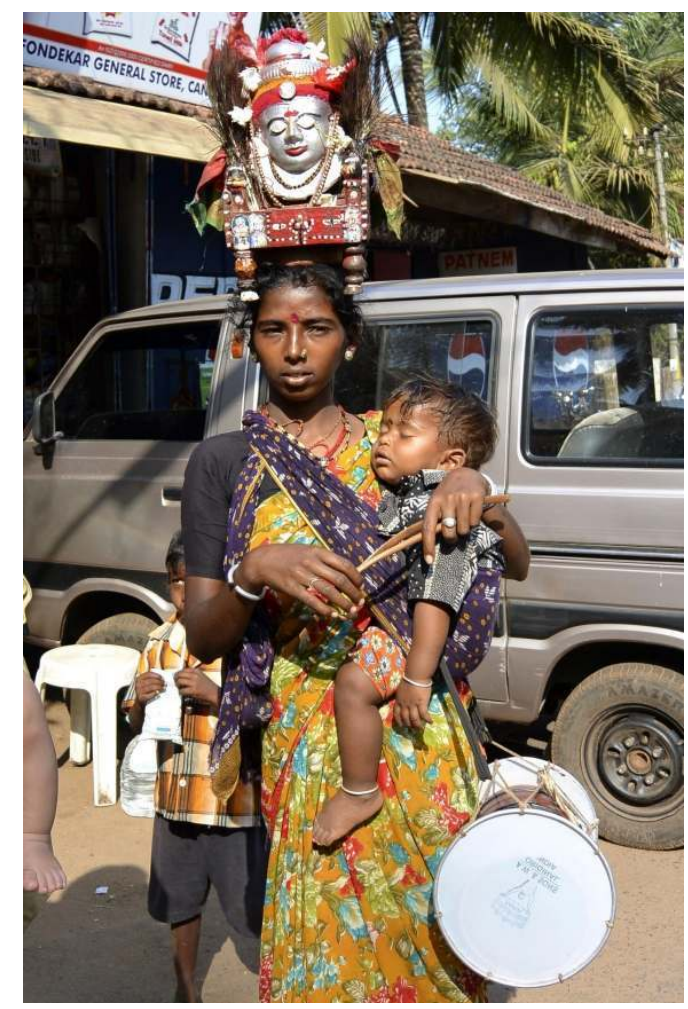

Portable shrine with the image of a local goddess carried by a Potraj woman on foot. Patnem, Goa. Photo credits: Borayin Larios.

\section{Figure 16a}

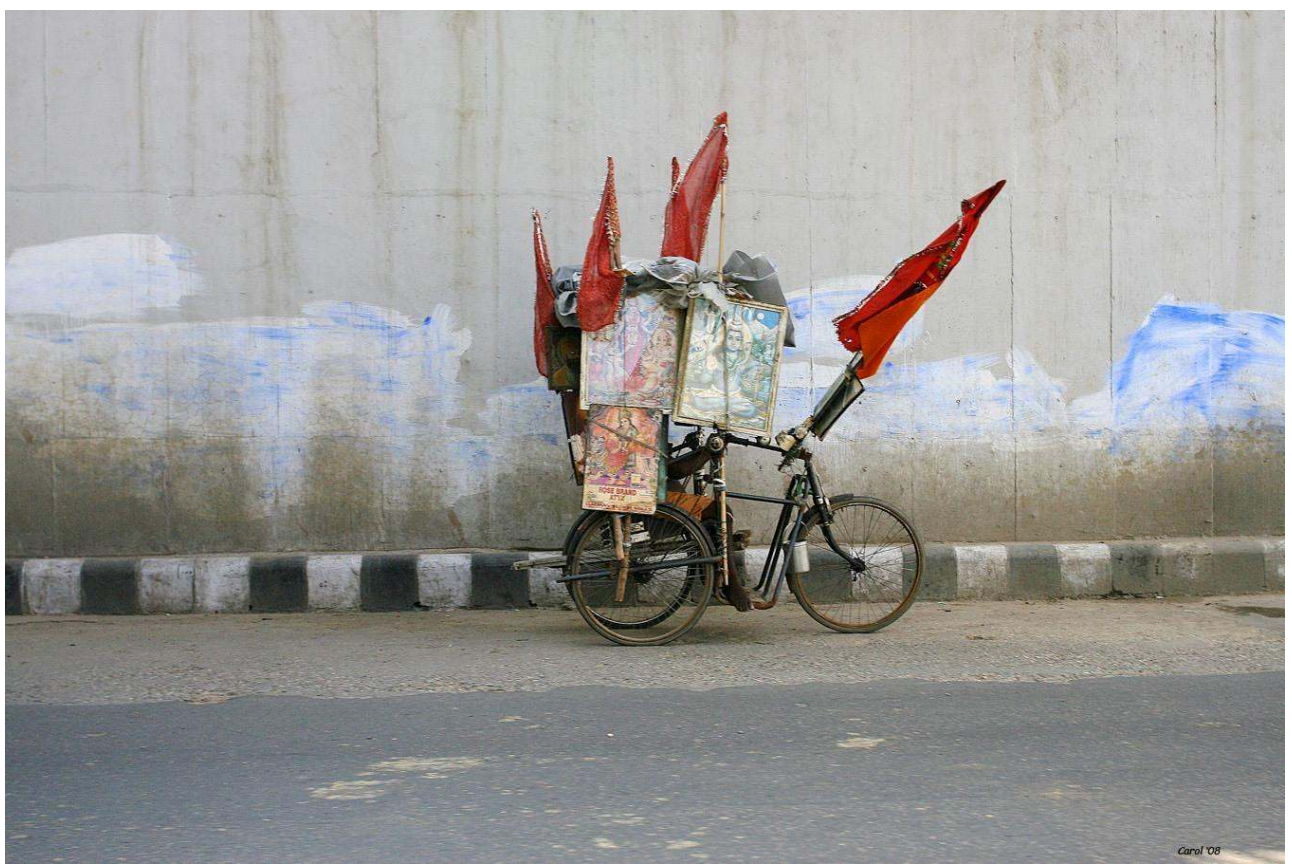

Portable shrine on a bicycle. Ring Road, New Delhi.

Photo credits: Carol Mitchell. https://www.flickr.com/photos/webethere/2705694973/ 
Figure 16b

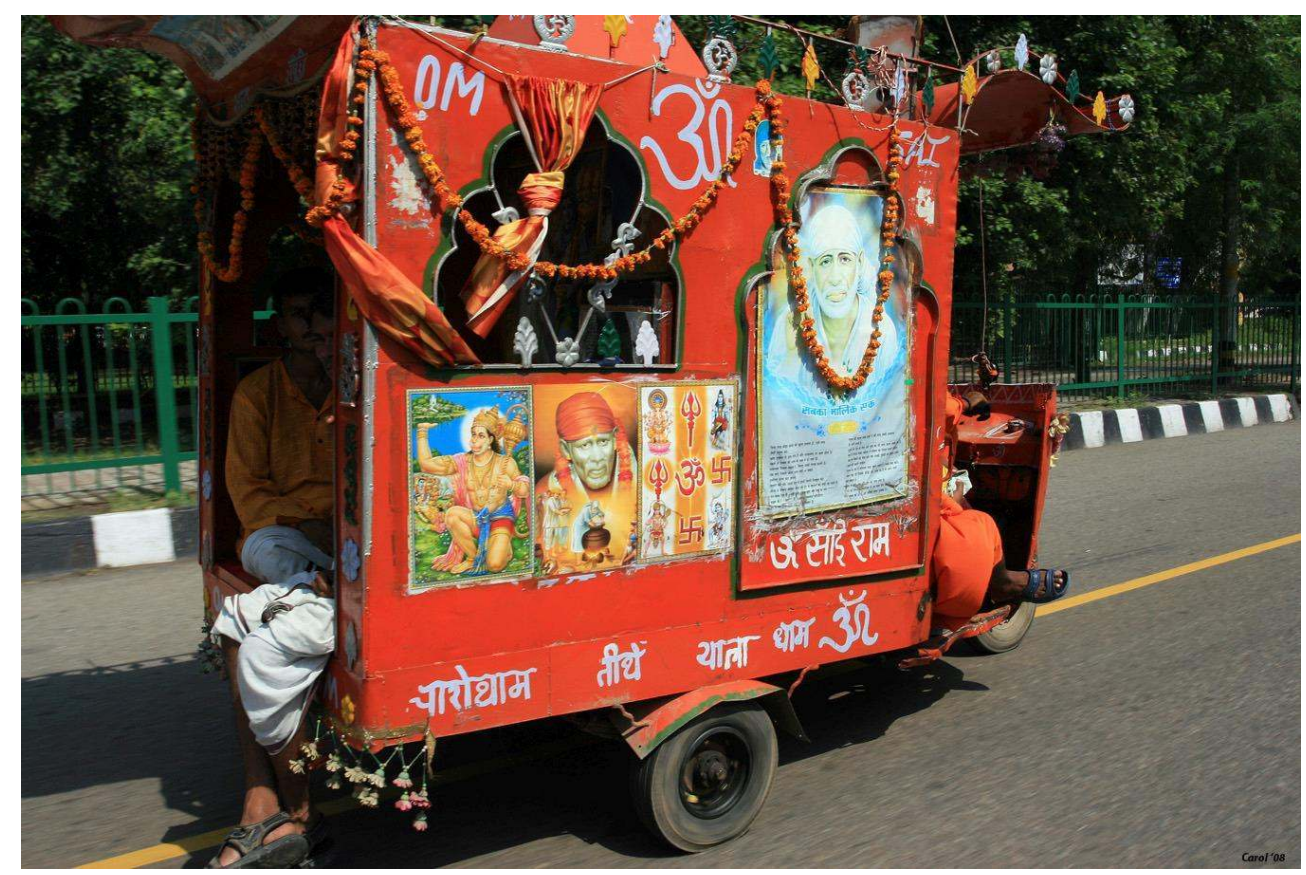

Portable shrine on a rickshaw. Ring Road, New Delhi.

Photo credits: Carol Mitchell. https://www.flickr.com/photos/webethere/3021852408/

Figure 17

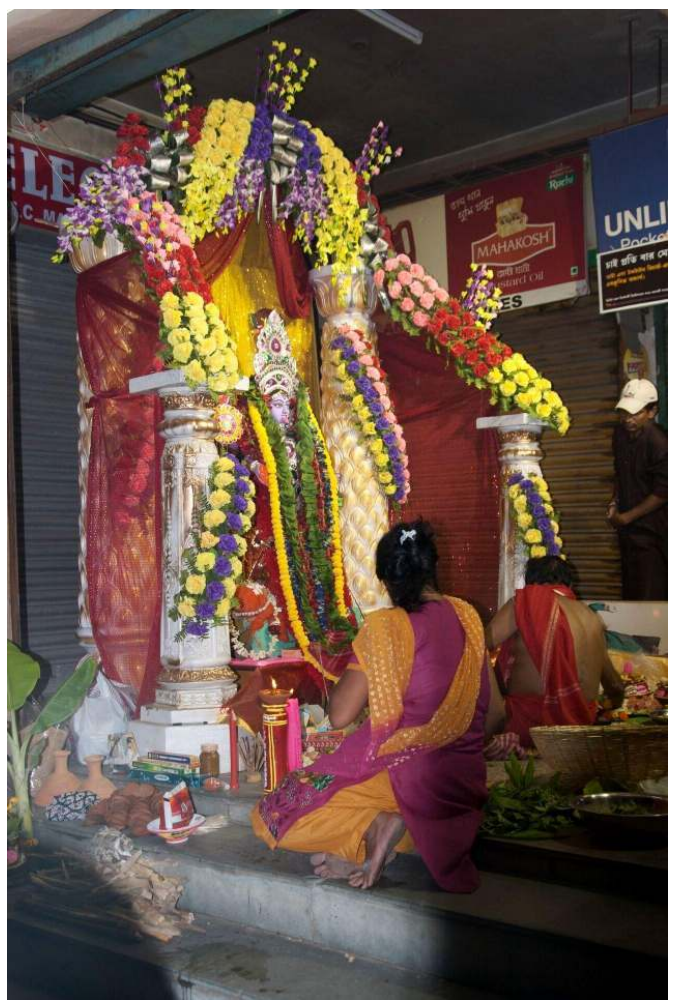

Ephemeral wayside shrine with an image of Kâli specifically built for the celebration of a religious festival, Kolkat.

Photo credits: Raphaël Voix. 
Figure 18

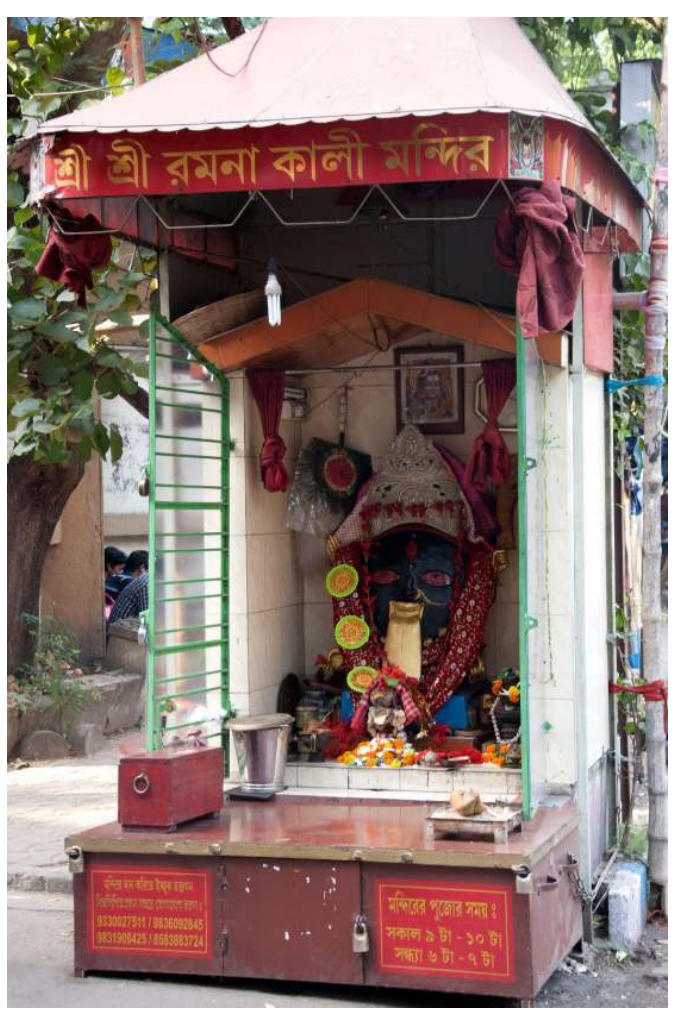

Wayside shrine dedicated to Kâli and that can be temporally enclosed for the night, Kolkata. Photo credits: Raphaël Voix.

Figure 19

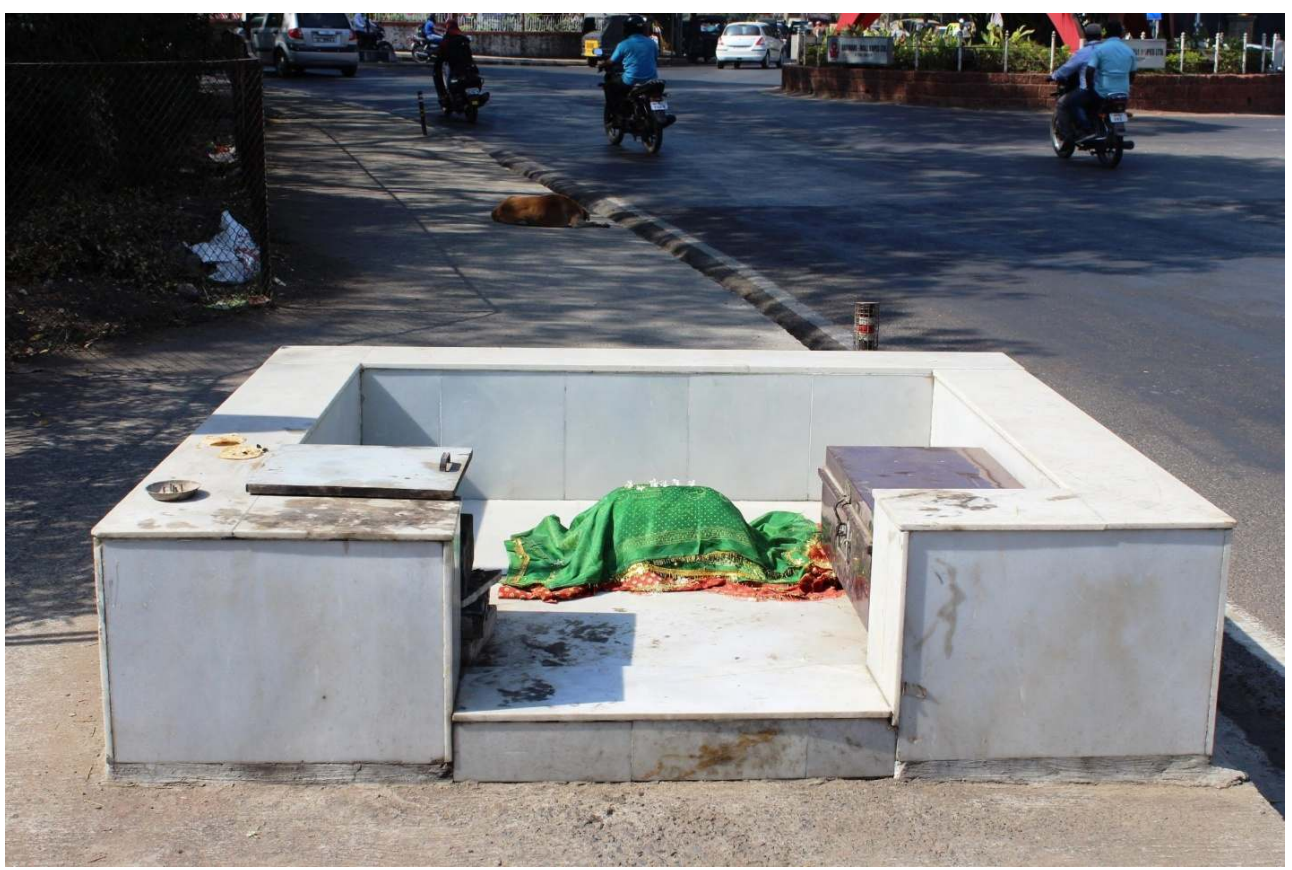

Wayside Dargāh on the pavement of Pashan Road, Pune. Photo credits: Borayin Larios. 
Figure 20

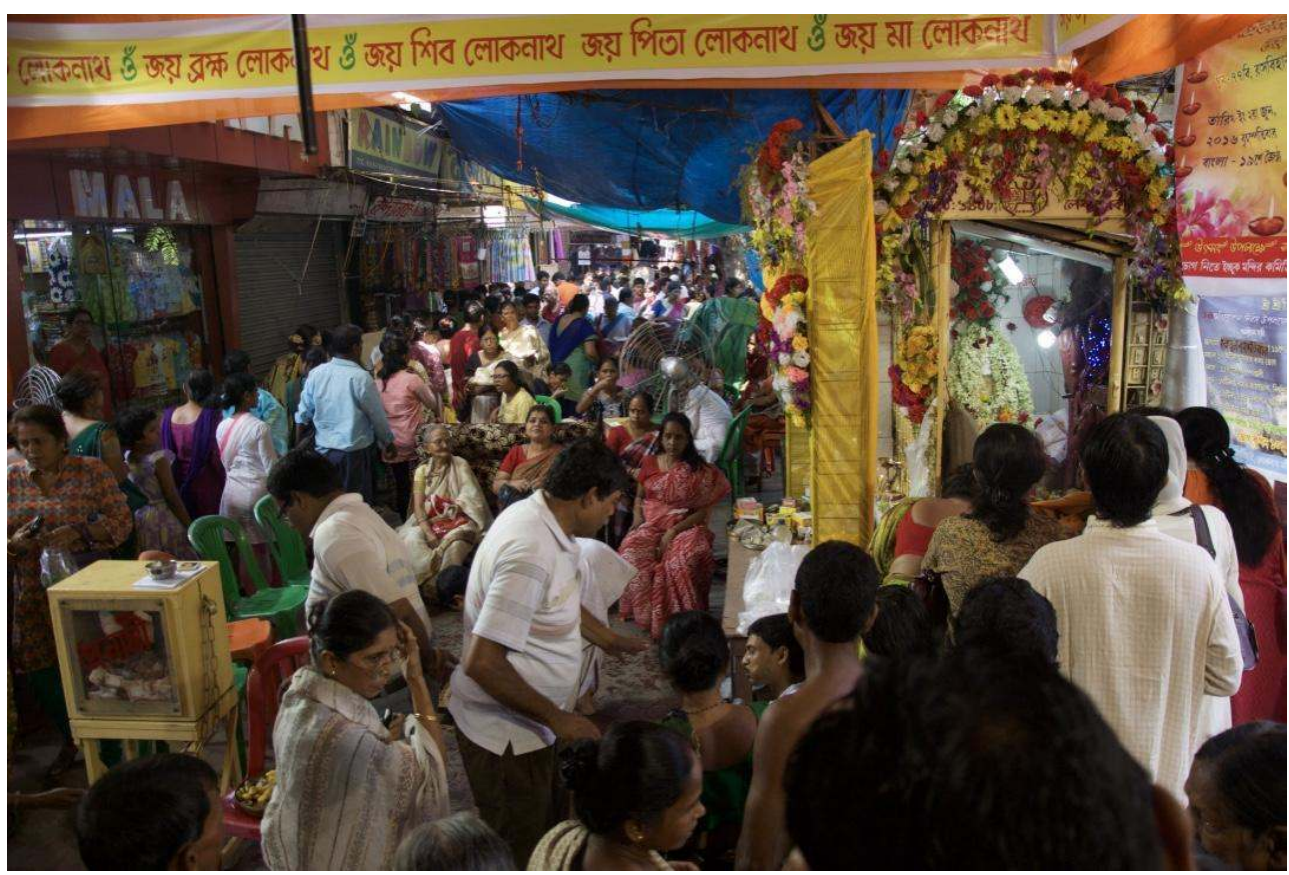

Wayside shrine that gathers a small crowd around it for its annual celebration, Kolkata. Photo credits: Raphaël Voix.

Figure 21

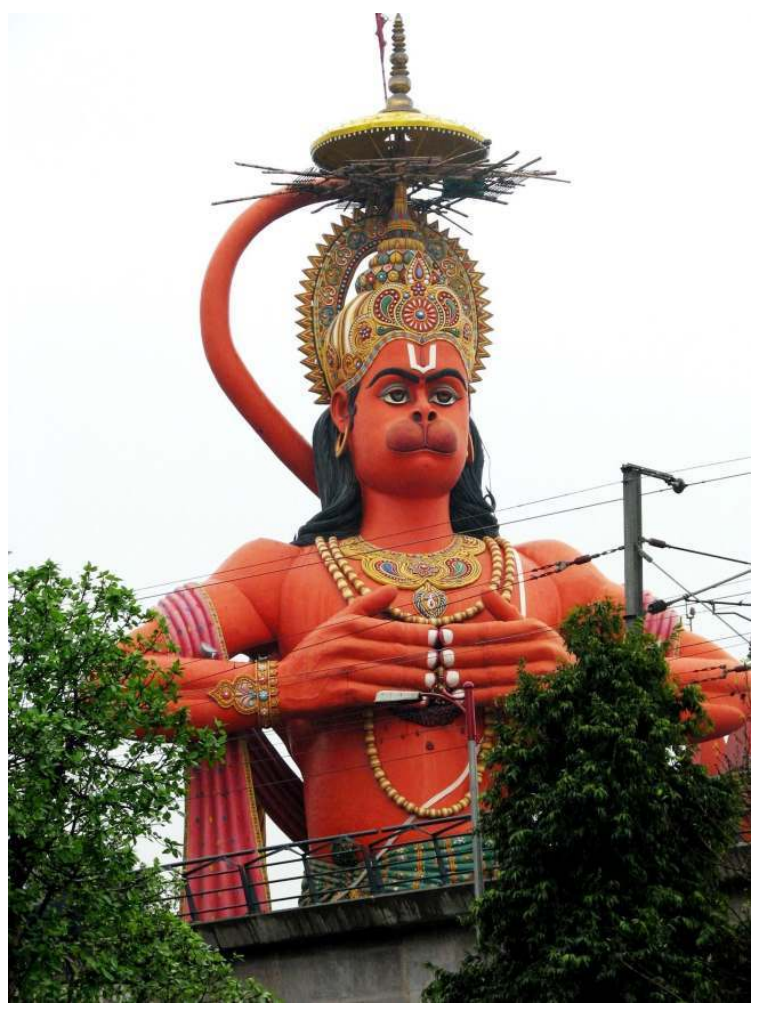

View of the Sankat Mocan Dhām Hanumān Mandir, near Jhandewalan metro station, Delhi. Photo Credit: Tico Bassie. https://www.flickr.com/photos/tico_bassie/5462878324/ 
Figure 22

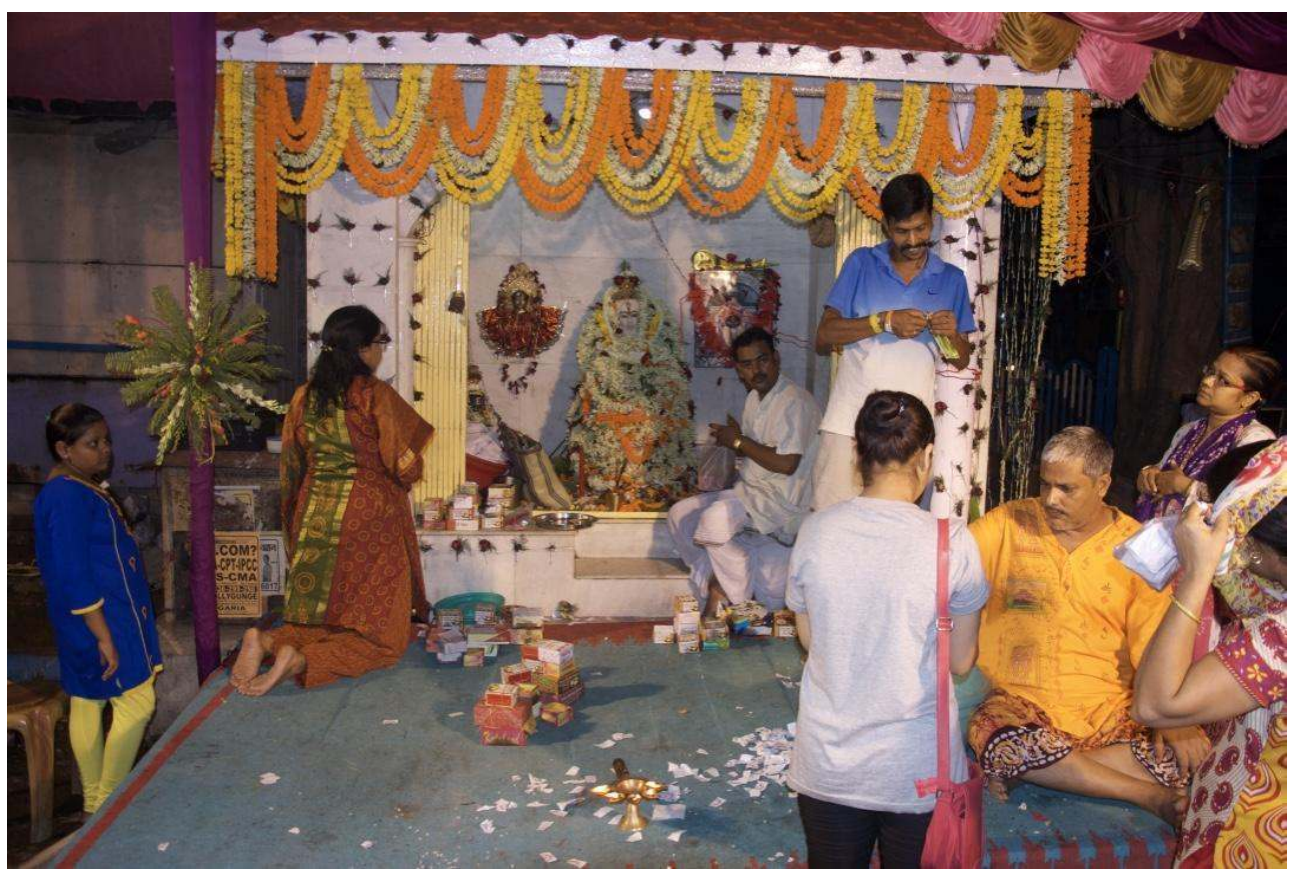

Where two people can comfortably sit for ritual interactions.

Photo credits: Raphaël Voix.

39 We are grateful to all the anonymous reviewers of SAMAJ for their helpful comments on a prior version of this introduction.

\section{BIBLIOGRAPHY}

Ahuja, Naman P. 2018. "The Dead, Dying, and Post-death: Visual Exemplars and Iconographic Devices." Pp. 85-99 in Imaginations of Death and the Beyond in India and Europe, edited by G. Blamberger and S. Kakar. Singapore: Springer Singapore.

Appadurai, Arjun. 1981. Worship and Conflict under Colonial Rule: A South Indian Case. Vol. 27. Cambridge: Cambridge University Press.

Asad, Talal. 1997. Genealogies of Religion: Discipline and Reasons of Power in Christianity and Islam. Baltimore: Johns Hopkins University Press.

Baxi, Upendra. 2007. “Commentary: Savarkar and the Supreme Court.” Pp. 47-58 in Ronojoy Sen. Legalizing Religion: The Indian Supreme Court and Secularism. Washington: East-West Center.

Bellamy, Carla. 2015. “Shrines, Religious Healing and Pilgrimage in South Asia." Pp. 262-75 in Routledge Handbook of Religions in Asia, edited by B. S. Turner and O. Salemink. London: Routledge. 
Bergmann, Christoph and Jürgen Schaflechner, eds. Forthcoming. Ritual Journeys. London: Routledge.

Berti, Daniela, Gilles Tarabout, and Raphaël Voix, eds. 2016. Filing Religion: State, Hinduism, and Courts of Law. New Delhi: Oxford University Press.

Berti, Daniela and Gilles Tarabout. 2018. "Presentation." South Asia Multidisciplinary Academic Journal 17. Retrieved May 8, 2018 (https://journals.openedition.org/samaj/4433).

Bhardwaj, Surinder M. 1983. Hindu Places of Pilgrimage in India. Berkeley: University of California Press.

Bharucha, Rustom, and Komal Kothari. 2003. Rajasthan, an Oral History: Conversations with Komal Kothari. New Delhi; New York: Penguin Global.

Bhuwania, Anuj. 2014. "Courting the People: The Rise of Public Interest Litigation in PostEmergency India." Comparative Studies of South Asia, Africa and the Middle East 34(2):314-35.

Blackburn, Stuart H. 1985. "Death and Deification: Folk Cults in Hinduism.” History of Religions 24 (3):255-74.

Brackett, Jeffrey M., 2006. "Practically Hindu: Contemporary Conceptions of Hanumān-Māruti in Maharashtra." PhD dissertation, Faculty of Arts and Sciences, University of Pittsburg.

Branfoot, Crispin. 2007. Gods on the Move: Architecture and Ritual in the South Indian Temple. London: Society for South Asian Studies.

Brosius, Christiane and Yousuf Saeed, eds. 2014. South Asia's Islamic Shrines and Transcultural Visuality. Retrieved July 16, 2018 (https://kjc-sv013.kjc.uni-heidelberg.de/visualpilgrim/ essays.php).

Braudel, Fernand. 1982. Civilization and Capitalism: $15^{\text {th }}-18^{\text {th }}$ Century. Vol. I, The Structure of Everyday Life. Berkeley: University of California Press.

Certeau, Michel de, and Steven Rendall. 1984. The Practice of Everyday Life. Berkeley: University of California Press.

Claveyrolas, Mathieu. 2003. Quand le temple prend vie. Atmosphère et dévotion à Bénarès. Paris: CNRS éditions.

Colwell-Chanthaphonh, Chip and Maya de Salle-Essoo. 2014. "Saints and Evil and the Wayside Shrines of Mauritius." Journal of Material Culture Vol. 1, 19(3):253-77.

Dallapiccola, Anna L., ed. 1985. Beiträge zur Südasienforschung. Vol. 100, Vijayanagara-City and Empire: New Currents of Research. Stuttgart: Steiner-Verlag-Wiesbaden.

Deva, Surya. 2010. "Public Interest Litigation in India: A Quest to Achieve the Impossible?" Pp. 57-79 in Public Interest Litigation in Asia, edited by P. J. Yap and H. Lau. London: Routledge.

Eck, Diana L. 1998. Darśan: Seeing the Divine Image in India. $3^{\text {rd }}$ ed. New York, NY: Columbia University Press.

Eck, Diana L. 2012. India: A Sacred Geography. New York: Three Rivers Press.

Elison, William. 2014. "Sai Baba of Bombay: A Saint, His Icon, and the Urban Geography of Darshan." History of Religions 54(2):151-87.

Elison, William. 2018. "Site, Sight, Cite: Conceptualizing Wayside Shrines as Visual Culture." SAMAJ 18. Retrieved July 17, 2018 (https://journals.openedition.org/samaj/4540). 
Erndl, Kathleen M. 1993. Victory to the Mother: The Hindu Goddess of Northwest India in Myth, Ritual, and Symbol. Oxford: Oxford University Press.

Feldhaus, Anne. 2006. Connected Places: Region, Pilgrimage, and Geographical Imagination in India. New York: Palgrave Macmillan.

Flueckiger, Joyce B., and Jamini Roy. 2015. Everyday Hinduism. Chichester, England: Wiley Blackwell.

Foucault, Michel. 1978-86. The History of Sexuality. London: Allen Lane.

Freitag, Sandria B. 1989. Collective Action and Community: Public Arenas and the Emergence of Communalism in North India. Berkeley: University of California Press.

Fuller, Christopher J. 1984. Servants of the Goddess: The Priests of a South Indian Temple. Vol. 47. Cambridge; New York: Cambridge University Press.

Fuller, Christopher J. 2003. The Renewal of the Priesthood: Modernity and Traditionalism in a South Indian Temple. Princeton, NJ; Oxford: Princeton University Press.

Fuller, Christopher J. 1988. "Hinduism and Scriptural Authority in Modern Indian Law." Comparative Studies in Society and History 30(2):225-48.

Galanter, Marc. 1989. Law and Society in Modern India, edited with an introduction by Rajeev Dhavan. New Delhi; New York: Oxford University Press.

Ghassem-Fachandi, Parvis. 2012. "The City Threshold: Mushroom Temples and Magic Remains in Ahmedabad." Ethnography 13(1):12-27.

Goddard, Pliny Earle. 1913. "Wayside Shrines in Northwestern California." American Anthropologist , New Series, 15(4):702-03.

Gold, Daniel. 2015. Provincial Hinduism: Religion and Community in Gwalior City. New York: Oxford University Press

Gooptu, Nandini. 1997. “The Urban Poor and Militant Hinduism in Early Twentieth Century Uttar Pradesh.” Modern Asian Studies 31(4):879-918.

Gooptu, Nandini. 2001. The Politics of the Urban Poor in Early Twentieth-Century India. Cambridge: Cambridge University Press.

Haberman, David L. 1994. Journey through the Twelve Forests: An Encounter with Krishna. New York: Oxford University Press.

Hancock, Mary E. 1999. Womanhood in the Making: Domestic Ritual and Public Culture in Urban South India. Boulder: Westview Press.

Hancock, Mary, and Smriti Srinivas. 2008. "Spaces of Modernity: Religion and the Urban in Asia and Africa." International Journal of Urban and Regional Research 32(3):617-30.

Hardy, Adam. 2007. The Temple in South Asia. London: British Association for South Asian Studies. Harlan, Lindsey. 2003. The Goddesses' Henchmen: Gender in Indian Hero Worship. Oxford; New York: Oxford University Press.

Harman, William. 2012. "From Fierce to Domesticated: Mariyamman Joins the Middle Class." Nidan: International Journal for Indian Studies 24(1):41-65.

Haskett, Christian. 2018. “On Varanasi's Tiny Temples.” SAMAJ 18. Retrieved July 17, 2018 ( https://journals.openedition.org/samaj/4524). 
Henn, Alexander. 2006. “The Lord of Mapusa. Genesis of an Urban God in Goa." Pp. 31-47 in Rites hindous. Transferts et transformations, edited by G. Tarabout and G. Colas. Paris: Éditions de l'EHESS, Purușārtha 25.

Henn, Alexander. 2008. "Crossroads of Religions: Shrines, Mobility and Urban Space in Goa." International Journal of Urban and Regional Research 32(3):658-70.

Henn, Alexander. 2018. "Shrines of Goa: Iconographic Formation and Popular Appeal." SAMAJ 18. Retrieved July 17, 2018 (https://journals.openedition.org/samaj/4533).

Hindu Janajagruti Samiti. 2013. Hindu Janajagruti Samiti, August 20. Retrieved January 4, 2018 ( https://www.hindujagruti.org/news/17126.html).

Jacobsen, Knut A. 2013. Pilgrimage in the Hindu Tradition: Salvific Space. London: Routledge.

Jacobsen, Knut A., ed. 2009. South Asian Religions on Display: Religious Processions in South Asia and in the Diaspora. London: Routledge.

Jacobsen, Knut A. 2014. "Hinduism and Globalization." Pp. 359-72 in Routledge Handbook of Religions in Asia, edited by B. S. Turner and O. Salemink. New York: Routledge.

Jacobsen, Knut, A. 2017. "Pilgrimage: tìrthayātrā." Pp. 335-46 in The Oxford History of Hinduism. Hindu Law: A New History of Dharmaśāstra, edited by P. Olivelle and D. R. Davis. Oxford: Oxford University Press.

Jain Kajri, 2007. Gods in the Bazaar: The Economies of Indian Calendar Art. Durham: Duke University Press.

Janhit Manch v. State of Maharashtra. 2002. Bombay High Court, ordinary original civil jurisdiction, Writ Petition No. 2063.

Jaskūnas, Valdas. 2008. "Measuring the Body of God: Temple Plan Construction and Proportional Measurement in Early Texts on North Indian Architecture.” Acta Orientalia Vilnensia 9(2):83-123

Kalpagam, Uma. 2006. “Secularism, Religiosity and Popular Culture: Chennai’s Roadside Temples." Economic and Political Weekly 41(43/44):4595-600.

Kasinathan, Natana. 1978. Hero-stones in Tamilnadu. Madras: Arun Publications.

Kent, Eliza F. "Bus-Stop Sami: Transient Temples in Urban South India." SAMAJ 18. Retrieved July 17, 2018 (https://journals.openedition.org/samaj/4554).

Kinsley, David R. 1997. Hindu Goddesses: Visions of the Divine Feminine in the Hindu Religious Tradition. With a New Preface. Berkeley; California; London: University of California Press.

Kothari, Komal. 1982. “The Shrine: an Expression of Social Needs.” Pp. 5-31 in Gods of Byways: Wayside Shrines of Rajasthan, Madhya Pradesh and Gujarat, edited by J. Elliott and D. Elliot. Oxford: Museum of Modern Art.

Kramrisch, Stella, and Raymond Burnier. [1946] 2002. The Hindu Temple. Delhi: Motilal Banarsidass.

Kripke, Saul A. 1981. Naming and Necessity. $2^{\text {nd }}$ ed. Cambridge, Massachusetts: Harvard University Press.

Laermans, Rudi. 2016. "The Ambivalence of Religiosity and Religion: A Reading of Georg Simmel.” Social Compass 53(4):479-89.

Larios, Borayin. 2018. "From the Heavens to the Streets: Pune's Wayside Shrines." SAMAJ 18.

Retrieved July 17, 2018 (https://journals.openedition.org/samaj/4549). 
Lefebvre, Henri, John Moore, and Michel Trebitsch. [1947] 1991. Critique of Everyday Life. London: Verso.

Lidova, Natalia. 2010. “The Changes in Indian Ritualism: Yajña versus Pūjā.” Pp. 205-31 in Archaeology and Text: The Temple in South Asia, edited by H. P. Ray. Oxford: Oxford University Press.

Lohokare, Madhura. 2016. "Neighborhood Associations in Urban India: Intersection of Religion and Space in Civic Participation." Pp. 167-83 in Place/No-Place in Urban Asian Religiosity, edited by J. P. Waghorne. New York: Springer.

Lorenzetti, Tiziana. 2015. Understanding the Hindu Temple: History, Symbols and Forms. Vol. 2. Berlin: EB-Verlag.

Mazumdar, Shampa and Sanjoy Mazumdar. 1994. "Of Gods and Homes: Sacred Space in the Hindu House." Environments 22(2):41-49.

McLain, Karline. 2016. "Visual and Media Culture." Pp. 227-42 in Hinduism in the Modern World, edited by B. Hatcher. New York: Routledge.

McLeod, W. H. 1978. "On the Word panth: A Problem of Terminology and Definition." Contributions to Indian Sociology 12(2):287-95.

Michell, George. 1988. The Hindu Temple: An Introduction to Its Meaning and Forms. Chicago: London: University of Chicago Press.

Mills, Martin A. 2003. Identity, Ritual and State in Tibetan Buddhism: The Foundations of Authority in Gelukpa Monasticism. London; New York: Routledge Curzon.

Mines, Diane P. 2012. “Loss and Recognition: The Historical Force of a Goddess.” Nidān: International Journal for the Study of Hinduism 24:1-15.

Mohammad, Afsar. 2013. "The Sri Venkateswara Temple in Tirupati." Pp. 232-44 in Religions in Focus, Contemporary Hinduism, edited by P. P. Kumar. Durham, UK: Acumen.

Monger, George. 1997. “Modern Wayside Shrines." Folklore 108(1-2):113-14.

Morson, Gary S. 2013. Prosaics and Other Provocations: Empathy, Open Time, and the Novel. Boston, MA: Academic Studies Press.

Moodie, Deonnie. Forthcoming. "Kālīghāṭ and the Fashioning of Middle Class Modernities." International Journal of Hindu Studies.

Mookerjee, Priya. 1987. Pathway Icons: The Wayside Art of India. London: Thames and Hudson.

Morinis, E. Alan. 1984. Pilgrimage in the Hindu Tradition: A Case Study of West Bengal. Delhi: Oxford University Press.

Morson, Gary S., and Caryl Emerson. 1992. Mikhail Bakhtin: Creation of a Prosaics. Stanford, CA: Stanford University Press.

Nanda, Meera. 2011. The God Market: How Globalization is Making India More Hindu. New York: NYU Press.

Nair, Supriya M. 2013. "Domestic Altars, Female Avatars: Hindu Wives and Widows in Lakshmi Persaud's 'Raise the Lanterns High.”' Pp. 48-69 in Routledge Research in Postcolonial Literatures: Critical Perspectives on Indo-Caribbean Women's Literature, edited by J. A. I. Mahabir and M. Pirbhai. New York: Routledge.

Olivelle, Patrick, and Donald R. Davis. 2017. The Oxford History of Hinduism. Hindu Law: A New History of Dharmaśāstra. Oxford: Oxford University Press. 
Orr, Leslie C. 2000. Donors, Devotees, and Daughters of God: Temple Women in Medieval Tamilnadu. New York, NY: Oxford University Press.

Orsi, Robert A. 2012. "Afterword: Everyday Religion and the Contemporary World: The Unmodern, or What Was Supposed to Have Disappeared but Did Not." Pp. 146-60 in EASA Series, Vol. 18, Ordinary Lives and Grand Schemes: Anthropology of Everyday Religion, edited by S. Schielke and L. Debevec. New York, NY: Berghahn Books.

Østerberg, Anna Charlotta. 2018. "The Role of Roadside Shrines in the Everyday Lives of Female Devotees in Mumbai." SAMAJ 18. Retrieved July 17, 2018 (https://journals.openedition.org/ samaj/4565).

Padma, Sree. 2013. Vicissitudes of the Goddess: Reconstructions of the Gramadevata in India's Religious Traditions. New York: Oxford University Press.

Pike, Kenneth L. 1967. Language in Relation to a Unified Theory of the Structure of Human Behavior. The Hague: Mouton and Company.

Pinney, Christopher. 2004. Photos of the Gods: The Printed Image and Political Struggle in India. London: Reaktion.

Presler, Franklin A. 1987. Religion under Bureaucracy: Policy and Administration for Hindu Temples in South India. Cambridge: Cambridge University Press.

Preston, Laurence W. 2002. "Shrines and Neighbourhood in Early Nineteenth-century Pune, India." Journal of Historical Geography 28(2):203-15.

Ray, Himanshu P. 2010. Archaeology and Text: The Temple in South Asia. Oxford: Oxford University Press.

Reddy, Deepa, and John Zavos. 2010. "Temple Publics: Religious Institutions and the Construction of Contemporary Hindu Communities." International Journal of Hindu Studies 13(3):241-60.

Richardson, Milda Bakšys. 2005. "Reverence and Resistance in Lithuanian Wayside Shrines." Perspectives in Vernacular Architecture 10:249-67.

Richardson, Milda Bakšys. 2015. "Iconoclasm and Resistance: Wayside Shrines in the Struggle for Lithuanian Independence.” Pp. 103-15 in Architecture and Armed Conflict, edited by J. M. Mancini and K. Bresnahan. London; New York: Routledge.

Richardson, Milda Bakšys. 1998. "Lithuanian Wayside Shrines.” Pp. 23-30 in Sacred Wood: The Contemporary Lithuanian Woodcarving Revival, edited by R. T. Saliklis. Madison: Elvehjem Museum of Art, University of Wisconsin.

Säävälä, Minna. 2003. “Auspicious Hindu Houses: The New Middle Classes in Hyderabad, India.” Social Anthropology 11(2):231-47.

Sahney, Puja. 2016. "Mandir and Visa Status: Purity, Auspiciousness and Hindu Homes in the USA." Material Religion 12(3):322-45.

Sahney, Puja. 2016. "Darśan, Decoration, and Transnational Hindu Homes in the United States." Asian Ethnology 75(2):279-302.

Santino, Jack. 2004. "Performative Commemoratives, the Personal, and the Public: Spontaneous Shrines, Emergent Ritual, and the Field of Folklore." The Journal of American Folklore 117(466):36372.

Sathe, Satyaranjan Purushottam. 2002. Judicial Activism in India: Transgressing Borders and Enforcing Limits. New Delhi: Oxford University Press. 
Schlemmer, Grégoire. "Enshrining Space: Shrines, Public Space and Hinduization among the Kulung of Nepal.” SAMAJ 18. Retrieved July 17, 2018 (https://journals.openedition.org/ samaj/4603).

Sekine, Yasumasa. 2006. "Sacralization of the Urban Footpath, with Special Reference to Pavement Shrines in Chennai City, South India.” Temenos 42(2):79-92.

Sequeira, Rosy. 2016. "Raze Illegal Shrines by December 31: Bombay High Court Tells Government.” The Times of India, October 2. Retrieved June 28, 2018 (https:// timesofindia.indiatimes.com/city/mumbai/Raze-illegal-shrines-by-December-31-Bombay-HighCourt-tells-government/articleshow/54633852.cms).

Settar, Shadakshari, and Günther-Dietz Sontheimer, eds. 1982. Memorial Stones: A Study of their Origin, Significance, and Variety. Heidelberg: South Asia Institute, University of Heidelberg.

Schaflechner, Jüergen. 2018. Hinglaj Devi. Identity, Change, and Solidification at a Hindu Temple in Pakistan. New York: Owford University Press.

Shivam, Pushkal. 2016. “The Space of Street-side Religiosity.” Economic \& Political Weekly 51 (4):57.

Singh, Kabita. 2010. “The Temple's Eternal Return: Swaminarayan Akshardham Complex in Delhi." Artibus Asiae 70(1):47-76.

Sinha, Vineeta. 2016. "Marking Spaces as 'Sacred': Infusing Singapore’s Urban Landscape with Sacrality." International Sociology 31(4):467-48.

Snehi, Yogesh. 2018. "Spatiality, Memory and Street Shrines of Amritsar." SAMAJ 18. Retrieved July 17, 2018 (https://journals.openedition.org/samaj/4559).

Society for Fast Justice, through its President Ashish Mehta and Another v. The State of Maharashtra and Others, Mumbai High Court, 01 October 2016.

Srinivas, Smriti. 2015. A Place for Utopia: Urban Designs from South Asia. Washington: University of Washington Press.

Srinivas, Smriti. 2016. "Roadside Shrines, Storefront Saints, and Twenty-firstCentury Lifestyles: The Cultural and Spatial Thresholdsof Indian Urbanism.” Pp. 131-47 in Place/No-Place in Urban Asian Religiosity, edited by J. P. Waghorne. New York: Springer.

Srinivas, Smriti. 2018. "Roundtable on Spirited Topographies: Religion and Urban Place-Making Highways for Healing: Contemporaneous 'Temples' and Religious Movements in an Indian City.” Journal of the American Academy of Religion 32(3):230.

Stein, Burton. 1978. South Indian Temples: An Analytical Reconsideration. New Delhi: Vikas.

Subbiah, Shanmugam Pillai. 2006. "Religious Expressions of Urban Poor on Pavements and Religious Continuity of Overseas Indians: Some Observations from Chennai, India and San Francisco, USA." Pp. 75-123 in Remaking Traditional Knowledge: Knowledge as a Resource, edited by C. Daniels. Tokyo: Research Institute for Languages and Cultures of Asia and Africa.

Trouillet, Pierre-Yves. 2017. "Hindu Temples and Development of Localities in Tamil Nadu (South India)." Pp. 311-34 in Subaltern Urbanisation in India: Exploring Urban Change in South Asia, edited by E. Denis and M.-H. Zérah. Springer: New Delhi.

Union of India v. State of Gujarat \& Ors. 2009. Special Leave to Appeal (Civil) No(s).8519/2006 High Court of Gujarat at Ahmedabad). 
Urban, Hugh. 2009. The Power of Tantra: Religion, Sexuality and the Politics of South Asian Studies. London; New York: IB Tauris.

Vineeta, Sinha. 2005. A New God in the Diaspora? Muneeswaran Worship in Contemporary Singapore. Singapore: National University of Singapore Press \& Nordic Institute of Asian Studies.

Waghorne, Joanne P. 2004. Diaspora of the Gods: Modern Hindu Temples in an Urban Middle-Class World . Cary: Oxford University Press.

Waghorne, Joanne P., ed. 2016. Place/No-Place in Urban Asian Religiosity. Singapore: Springer.

Wittgenttein, Ludwig. 2006. Philosophical Investigations: The German Text, with a Revised English Translation. $3^{\text {rd }}$ ed. Oxford: Blackwell.

Warrier, Maya. 2003. Processes of Secularization in Contemporary India: Guru Faith in the Mata Amritanandamayi Mission. Modern Asian Studies 37(1):213-253.

Žižek, Slavoj. 2009. The Sublime Object of Ideology. London: Verso.

\section{NOTES}

1. See for example Haskett in this volume for Benares, or Gold (2015) for Gwalior.

2. See for example, Kramrisch and Burnier ([1946] 2002), Michell (1977), Dallapiccola (1985), Stein (1978), Appadurai (1981), Waghorne (2004), Hardy (2007), Branfoot (2007), Ray (2010), Orr (2000) and Lorenzetti (2015). On the role of Hindu temples in the development of urbanization in contemporary South India, see Trouillet (2017).

3. Examples of studies that focus on single temples are Fuller's work on the Mīnākṣi temple in Madurai (1984 and 2003) and Afsar Mohammed's study on Veṇkaṭeśvara (2013).

4. To do justice to the large body of literature on this topic and on "sacred" geography in general we would need to considerably expand the scope of this introduction, but it will suffice to mention a few titles: Bhardwaj (1983), Morinis (1984), Haberman (1994), Eck (2012), Feldhaus (2006), Jacobsen (2008; 2013) and Bergmann and Schaflechner (forthcoming).

5. Here is a mere sample of relevant works: Kingsley (1997), Erndl (1993), Padma (2013), Harman (2012) and Flueckiger and Roy (2015).

6. Some of the works on these types of memorial shrines are Settar and Sontheimer (1982), Blackburn (1985), Kasinathan (1978), Harlan (2003) and Ahuja (2018).

7. See Mazumdar and Mazumdar (1994), Harman (2012), Hancock (1999), Nair (2013) and Sahney (2016a; 2016b).

8. See Hancock and Srinivas (2008), Srinivas (2016; 2017), Mazumdar (2009), Waghorne (2004; 2016) and Gold (2015) to mention only a few.

9. However, it must be mentioned that such a project has existed in the past. Consecutively to a panel organized at the 2004 AAR in San Antonio, the late Selva J. Raj had planned to edit a book on the same subject Stop in the Name of God: Wayside Shrines in South Asia-a title inspired by the Motown song called "Stop in The Name of Love." However, due to his early death the project could not be finished. We sincerely thank Tracy Pintchamn who contributed to our ECSAS panel in 2016 and kindly put us in contact with all the authors who had planned to publish in that volume, some of whom have contributed to this issue.

10. The most important contributions are: Preston (2002), Henn (2006; 2008), Kalpagam (2006), Sekine (2006), Ghassem-Fachandi (2012), Elison (2014), Shivam (2016), Lohokare (2016), and Srinivas $(2016 ; 2018)$.

11. Therefore, in this case we might agree with Žižek in that the unity of our object is a retroactive effect of naming it (Žižek 2009:105) and in the Weberian sense never objectively real. 
12. Compared to the ones originating from Judeo-Christian traditions, only few words (mana, etc.) originating from non-Judeo-Christian traditions have worked themselves into the general lexicon of the anthropology of religion. Among them few originate from Indic religion: see for example, McLeod's interesting, and yet unsuccessful attempt, to replace the word sect with the word panth (Mcleod 1978).

13. See for example, mandir (Hindi/Marathi), mandal (Hindi/Marathi), mandap (Hindi/Marathi), devagrha (Hindi/Sanskrit), devasthān (Hindi/Marathi/Kannada), devhārā (Hindi/Sanskrit), deul, deval, devḷi (Marathi), devālāya (Hindi/Kannada/Sanskrit) ālayam (Telugu/Sanskrit), surāvāsa, surālāya, nivās (Hindi/Sanskrit), thhākūradvāra, garh, (Hindi/Sanskrit), stūpa (Hindi/Sanskrit, mostly for a particular form of Buddhist shrine), bastī (Hindi for Jain shrines), kșētram (Malayalam). Non-Sanskritic terms include Dravidian terms such as kōvil, kōyilil and kōyilukku (Tamil) and those derived from the Persian and Arabic dargāh, pīrkhānāa āstāna, takiya, mazār or maqbara (Urdu). For more on Muslim shrines see the contributions to the volume edited by Brosius and Saeed (2014).

14. Some vernacular languages use particular terms to differentiate between shrines and temples or more established houses of worship, for instance, when it comes to distinguishing "churches" from "shrines." See for example Bharucha and Kothari (2003:119-121) and Henn (this volume) who distinguishes between devuli, "small temple," or gumpti, grotto-shaped abode of gods or deified ancestors for Hindu shrines; and kopel, "chapel" or khuris, "cross," for Catholic shrines.

15. On the terms emic and etic see Pike (1966).

16. On the importance of calendar art in Indian public culture, see Pinney (2004) and Jain (2007).

17. For a nice collection of photographs of pathway icons as an idiom of Indian religious folk-art, with examples mainly taken from Rajasthan, see Mookerjee (1987).

18. While conducting surveys in South Asia, some researchers have used size as a specific marker of differentiation between shrines. Although it makes sense for the purpose of a local survey, it does not provide us with easily comparable data since the different categories used can sometimes substantially differ from one researcher to another, thus making any comparison difficult. For example, in his survey of places of worship conducted in the city of Gwalior, Daniel Gold distinguishes between: a small temple, that "can accommodate just a few people, easily for occasional worship"; a medium-sized temple where a group of around fifteen regular worshippers could be comfortably accommodated; and large temple that could easily seat "twenty five or more people for special religious talks and performances of devotional music by local groups" (Gold 2015:263). For a survey conducted in Benares, Haskett (this volume) uses the same categoriessmall, medium, and large-but with slightly different definitions: small temples-or "tiny temples," as he puts it-allow access for a single seated worshipper, and "often did not have an actual interior beyond the space that contained the deity image[s]"; medium temples are those "capacious enough to allow one or more worshippers to easily enter, but not to serve as a site for any sizable gathering"; and large are those temples that are able to "accommodate a significant number of persons" (Haskett, this volume). Thus, what Gold sees as a small temple in Gwalior, Haskett would consider as a medium temple in Benares.

19. The main reason for our use of the term "religiosity" versus "religion" is twofold: first, as many scholars have argued, the term "religion" has clear Eurocentric overtones, implying a coherent system of beliefs and practices that define a particular community; and second, because "religiosity" (as it has been theorized since Simmel) can be employed here to describe just such practices and material objects that, on the one hand draw from religious traditions in South Asia, and on the other challenge the boundaries and the coherence of precisely these systems. Indeed, in Simmel's view, the notion of "religion" always refers to the outcome of a process of separation and institutionalization of an already existing religiosity (Laermans 2016:481). 
20. As Schaflechner argues the attempt of several actors to make truth-claims about a particular tradition are often negotiated through a process of struggle that he suggests we call "the solidification of tradition" (Schaflechner 2018:36)

21. Although Hindu public temples are legally supposed to be open to all, still, in many places they are closed to non-Hindus, women and Dalits. Therefore, important places of worship are reserved exclusively to those who are eligible for entrance and who actually enter.

22. In Chennai, for example, Kalpagam sees it as a "working class" activity (Kalpagam 2006:4595)

23. See, for example, Claveryolas (2003).

24. For a study on the rise of militant Hinduism in the early twentieth century see Gooptu, who demonstrates that despite the common idea on the emergence of a seemingly uniform version of Hinduism cutting across caste and class, this revival was rather the very "terrain of struggle amongst various opposing sections of Hindus not simply over doctrine, but more but more crucially over the questions of class, status and power" (Gooptu 1997:40).

25. The NGO Janhit Manch through the voice of its president, Bhagvanji Raiani.

26. Quoted in Elison (2014:184).

27.

28. This interim measure follows the recommendation the Home Secretary-administrative head of the Ministry of Home Affairs-had articulated a few days earlier, on 29 September, together with all Chief Secretaries of the States. Let us note first that the phrase "illegal structures" here includes all illegal structures, no matter the size or type of organization, i.e. regardless of whether they are tiny wayside shrines on the pavement or fully institutionalized yet illegal temples, mosques or other types of religious structures. Second, the term "shrine" is not mentioned here.

29. See Society for Fast Justice, through its President Ashish Mehta and Another v. The State of Maharashtra and Others 2016.

30. See Sequeira (2016).

31. For an analysis of the importance of the technical and legalistic action of the courts-the arguments, the vocabulary in which they are couched, and the legal strategies used by the parties and by the Court- in the shaping of Hinduism, see (Berti, Tarabout, and Voix 2017).

\section{ABSTRACTS}

Drawing on this special issue's ethnographic data and analysis this introduction aims to offer an analytical framework for understanding the notion of wayside shrines. It does so by defining wayside shrines as sites that enshrine a worshipped object that is immediately adjacent to a public path, visible from it and accessible to any passerby. Further, we argue that wayside shrines are spaces in which we can observe a unique form of everyday religiosity that challenges sedimented discourses and practices at three different scales: at the level of the individual, of the community, and of the state.

\section{INDEX}

Keywords: wayside shrines, popular religion, everyday religion, defiant religiosity, India, public space 


\section{AUTHORS}

\section{BORAYIN LARIOS}

French National Center for Scientific Research (CNRS) and University of Heidelberg

RAPHAËL VOIX

French National Center for Scientific Research (CNRS) 